Louisiana State University

LSU Digital Commons

5-18-2015

\title{
Unusual Example of Chelate Ring Opening upon Coordination of the 9-Ethylguanine Nucleobase to [Pt(di- (6-methyl-2-picolyl)amine) Cl] Cl
}

\author{
Chase Andrepont \\ Louisiana State University \\ Svetlana Pakhomova \\ Louisiana State University \\ Patricia A. Marzilli \\ Louisiana State University \\ Luigi G. Marzilli \\ Louisiana State University
}

Follow this and additional works at: https://digitalcommons.Isu.edu/biosci_pubs

\section{Recommended Citation}

Andrepont, C., Pakhomova, S., Marzilli, P., \& Marzilli, L. (2015). Unusual Example of Chelate Ring Opening upon Coordination of the 9-Ethylguanine Nucleobase to [Pt(di-(6-methyl-2-picolyl)amine)Cl]Cl. Inorganic Chemistry, 54 (10), 4895-4908. https://doi.org/10.1021/acs.inorgchem.5b00496

This Article is brought to you for free and open access by the Department of Biological Sciences at LSU Digital Commons. It has been accepted for inclusion in Faculty Publications by an authorized administrator of LSU Digital Commons. For more information, please contact ir@lsu.edu. 


\title{
Unusual Example of Chelate Ring Opening upon Coordination of the 9-Ethylguanine Nucleobase to [Pt(di-(6-methyl-2-picolyl)amine)Cl]Cl
}

\author{
Chase Andrepont, Svetlana Pakhomova, Patricia A. Marzilli, and Luigi G. Marzilli* \\ Department of Chemistry, Louisiana State University, Baton Rouge, Louisiana 70803, United States \\ Supporting Information
}

ABSTRACT: Anticancer-active monofunctional Pt(II) complexes have bulky carrier ligands and bind to G residues in DNA, causing structural distortions. To gain fundamental chemical information on such monofunctional adducts, we assessed the 9-ethylguanine (9-EtG) adducts formed by $\left[\mathrm{Pt}\left(\mathrm{N}(\mathrm{H}) 6,6^{\prime}-\mathrm{Me}_{2} \mathrm{dpa}\right) \mathrm{Cl}\right] \mathrm{Cl}\left(\mathrm{N}(\mathrm{H}) 6,6^{\prime}-\mathrm{Me}_{2} \mathrm{dpa}=\right.$ di-(6-methyl-2-picolyl)amine ). 9-EtG added to $\left[\mathrm{Pt}\left(\mathrm{N}(\mathrm{H}) 6,6^{\prime}-\mathrm{Me}_{2} \mathrm{dpa}\right) \mathrm{Cl}\right] \mathrm{Cl}$ to form not only the expected $\left[\mathrm{Pt}\left(\mathrm{N}(\mathrm{H}) 6,6^{\prime}-\mathrm{Me}_{2} \mathrm{dpa}\right)(9-\mathrm{EtG})\right]^{2+}$ monoadduct having syn and anti conformers but also a $\left[\mathrm{Pt}\left(\mathrm{N}(\mathrm{H}) 6,6^{\prime}-\mathrm{Me}_{2} \mathrm{dpa}\right)(9-\mathrm{EtG})_{2}\right]^{2+}$ bisadduct consisting of $\Lambda \mathrm{HT}$ and $\Delta \mathrm{HT}$ conformers (HT = head-to-tail). For both

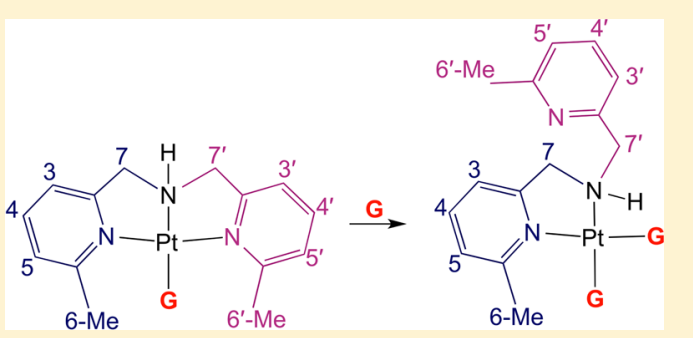
adducts, the two conformers exist as a dynamic equilibrium mixture. Concomitant with formation of the bisadduct, the binding mode of the $\mathrm{N}(\mathrm{H}) 6,6^{\prime}-\mathrm{Me}_{2}$ dpa ligand converts from tridentate to bidentate. A Pt(II)-bound 6-methyl-2-picolyl chain and the secondary amine constitute the bidentate chelate ring. The other 6-methyl-2-picolyl chain is dangling. The secondary nitrogen is an asymmetric center, and each conformer exists as a racemic mixture of two enantiomers. For a given configuration at the secondary amine of the $\left[\mathrm{Pt}\left(\mathrm{N}(\mathrm{H}) 6,6^{\prime}-\mathrm{Me}_{2} \mathrm{dpa}\right)(9-\mathrm{EtG})_{2}\right]^{2+}$ adduct, the more abundant HT conformer can form a hydrogen bond between the $\mathrm{NH}$ of the bidentate ligand and the cis 9-EtG O6. $\left[\mathrm{Pt}\left(\mathrm{N}(\mathrm{H}) 6,6^{\prime}-\mathrm{Me} \mathrm{dpa} \mathrm{Cl}\right] \mathrm{Cl}\right.$ forms the monoadduct in $\sim 1 /$ 20 the time for its parent, $[\mathrm{Pt}(\mathrm{N}(\mathrm{H}) \mathrm{dpa}) \mathrm{Cl}] \mathrm{Cl}(\mathrm{N}(\mathrm{H}) \mathrm{dpa}=\operatorname{di}(2$-picolyl)amine), which exhibited typical behavior in forming only a monoadduct. We attribute the unusual new findings for $\left[\mathrm{Pt}\left(\mathrm{N}(\mathrm{H}) 6,6^{\prime}-\mathrm{Me}_{2} \mathrm{dpa}\right) \mathrm{Cl}\right] \mathrm{Cl}$ to $\mathrm{Pt}-\mathrm{N}$ bond weakening induced by the steric bulk of 6/6'-Me groups. We hypothesize that undetectable intermediates with a dangling 6-methyl-2-picolyl chain facilitate both rapid monoadduct formation and also bisadduct formation. Consistent with the intermediacy of such species with a dangling chain, addition of $\mathrm{HCl}$ to a $\left[\mathrm{Pt}\left(\mathrm{N}(\mathrm{H}) 6,6^{\prime}-\mathrm{Me}_{2} \mathrm{dpa}\right) \mathrm{Cl}\right] \mathrm{Cl}$ solution readily produced a dichloro complex with the $\mathrm{N}(\mathrm{H}) 6,6^{\prime}-\mathrm{Me}_{2}$ dpa chelate ligand in the bidentate mode, whereas $\mathrm{HCl}$ addition had no effect on $[\mathrm{Pt}(\mathrm{N}(\mathrm{H}) \mathrm{dpa}) \mathrm{Cl}] \mathrm{Cl}$.

\section{INTRODUCTION}

Difunctional platinum compounds of the type cis- $\mathrm{Pt}\left(\mathrm{L}^{\mathrm{bi}}\right) \mathrm{X}_{2}\left[\mathrm{~L}^{\mathrm{bi}}\right.$ $=$ one bidentate or two cis unidentate amine $\mathrm{N}$ donors; $\mathrm{X}_{2}=$ one bidentate or two monodentate anionic leaving groups], including cisplatin (cis-Pt $\left.\left(\mathrm{NH}_{3}\right)_{2} \mathrm{Cl}_{2}\right)$ and its analogues, are among the most effective and most studied anticancer agents. ${ }^{1-7} \mathrm{Pt}(\mathrm{II})$ compounds interact with DNA to form a 1,2-intrastrand $G^{*} G^{*}$ cross-link, with Pt linking the N7 of two guanines in adjacent $G$ residues of $\mathrm{DNA}^{5,6,8-13}\left(\mathrm{G}^{*}\right.$ identifies N7-platinated G residues in DNA or oligonucleotides). An Xray/NMR-derived model of a duplex 9-oligomer ${ }^{10}$ and an X-ray structure of an HMG-bound 16-oligomer, ${ }^{11}$ both containing the intrastrand cisplatin lesion, led us to focus on the distortions involving the $\mathrm{X} \cdot \mathrm{Y}$ base pair (bp) adjacent to the $5^{\prime}-G^{*} \cdot C$ bp in the $5^{\prime}$ direction along the duplex. ${ }^{10,14-16}$ The $X$. $\mathrm{G}^{*}$ bp has a large positive slide and a large positive shift. ${ }^{10,14} \mathrm{An}$ oligomer adduct of a rather bulky monofunctional $\mathrm{Pt}$ anticancer agent showed a similar shift and slide of the $\mathrm{XG}^{*}$ bp step adjacent to the $5^{\prime}-\mathrm{G}^{*} \cdot \mathrm{C}$ bp along the $5^{\prime}$ direction of the duplex. $^{13,17}$

Guanine bases coordinated in positions cis to a metal can have a head-to-tail (HT) or a head-to-head $(\mathrm{HH})$ orientation (Figure 1). For $\mathrm{Pt}\left(\mathrm{L}^{\mathrm{bi}}\right) \mathbf{G}_{2}$ adducts (bold $\mathbf{G}=$ guanine derivative bound to a metal but not tethered to another nucleobase), the
G bases preferentially adopt the HT orientation. ${ }^{18-22}$ In contrast, bases tethered by a sugar phosphate backbone, such as in $\mathrm{Pt}\left(\mathrm{L}^{\mathrm{bi}}\right)\left(\mathrm{d}\left(\mathrm{G}^{*} \mathrm{p} \mathrm{G}^{*}\right)\right)$ cross-link adducts, are most often found in the $\mathrm{HH}$ orientation, especially when a $5^{\prime}$-residue is present on the $5^{\prime}-G^{*}$ (for example, in $\mathrm{Pt}\left(\mathrm{L}^{\mathrm{bi}}\right)\left(\mathrm{d}\left(\mathrm{TG} \mathrm{G}^{*} \mathrm{G}^{*} \mathrm{~T}\right)\right.$ ) adducts). ${ }^{15,20-22}$ Because the guanine $\mathrm{H} 8$ (Figure 1) ${ }^{1} \mathrm{H}$ NMR signals are singlets and downfield, they are the most useful signals for assessing metal binding and the presence of rotamers. $^{15,16,23-28}$ Interconversions of $\mathrm{HH}$ to HT conformations via rotation about the $\mathrm{Pt}-\mathrm{N} 7$ bonds in cis-Pt $\left(\mathrm{L}^{\mathrm{bi}}\right) \mathrm{G}_{2}$ and cross-link adducts are rapid on the NMR time scale unless the $\mathrm{L}^{\text {bi }}$ carrier ligand is bulky. Bulky bidentate ligands lower the rotation rate, allowing observation of NMR signals of the conformers present in solution. For a difunctional agent, activity decreases and toxicity increases when $\mathrm{L}^{\mathrm{bi}}$ is bulky. ${ }^{5,29-32}$ The study of $\mathrm{Pt}\left(\mathrm{L}^{\mathrm{bi}}\right) \mathbf{G}_{2}$ adducts provides useful guidance and insight on ligand bulk and on whether such bulk can influence the properties of the bound nucleobase.

In contrast, monofunctional $\mathrm{Pt}(\mathrm{II})$ agents $\mathrm{Pt}\left(\mathrm{L}^{\text {tri }}\right) \mathrm{X}\left(\mathrm{L}^{\text {tri }}=\mathrm{a}\right.$ tridentate, one bidentate and one monodentate, or three monodentate ligands; $\mathrm{X}=$ a monodentate monoanionic leaving

Received: March 2, 2015

Published: April 24, 2015 


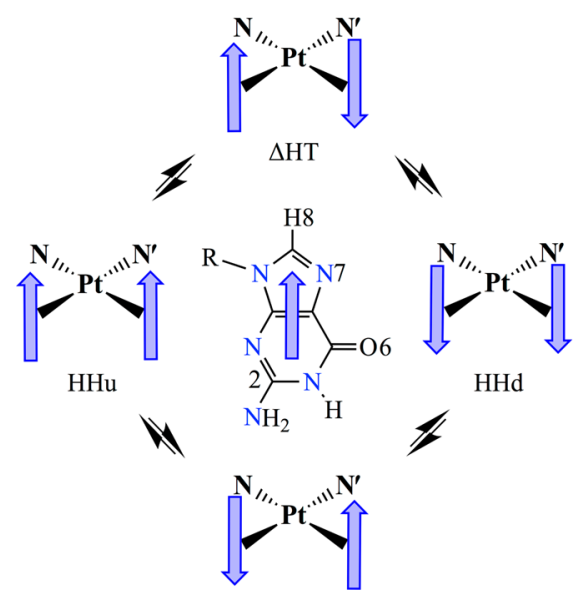

$\Lambda \mathrm{HT}$

Figure 1. Possible conformers for $\mathrm{Pt}\left(\mathrm{L}^{\mathrm{bi}}\right) \mathbf{G}_{2}$ adducts with two bound monodentate guanine N9 derivatives (referred to with a bold G). A generic version of $\mathbf{G}$ is depicted in the center, along with the guanine base numbering scheme. Note that the nucleobase is represented by an arrow with the tip at the guanine $\mathrm{H} 8$ atom. $\mathrm{N}$ and $\mathrm{N}^{\prime}$ represent a nitrogen donor ligand. When $\left(\mathrm{N} \neq \mathrm{N}^{\prime}\right)$, four rotamers $(\mathrm{HHu}, \mathrm{HHd}$, $\Lambda \mathrm{HT}, \Delta \mathrm{HT})$ are possible, whereas when $\left(\mathrm{N}=\mathrm{N}^{\prime}\right)$, only three conformers $(\mathrm{HH}, \Lambda \mathrm{HT}, \Delta \mathrm{HT})$ are possible because $\mathrm{HHu}=\mathrm{HHd}$. Regardless of whether the nitrogen donors are monodentate ligands or are part of a chelate $\left(\mathrm{N}-\mathrm{N}\right.$ or $\left.\mathrm{N}-\mathrm{N}^{\prime}\right)$, the same number of conformers can exist.

group) have higher activity when carrier-ligand bulk is greater. ${ }^{13,15,17,33-36}$ These monofunctional agents also preferentially bind to G residues in DNA. It is important to gain a better understanding of the fundamental features of such adducts. One approach to achieve this goal is to study $\mathrm{Pt}\left(\mathrm{L}^{\text {tri }}\right) \mathbf{G}$ models to assess the effects of steric interactions between the carrier ligand and the guanine base. We previously studied the interactions of a tridentate carrier ligand having in-plane bulk di-(2-picolyl)amine $(N(\mathrm{H}) \mathrm{dpa}$, Figure 2) in $\operatorname{Pt}(N(\mathrm{H}) \mathrm{dpa})$ G

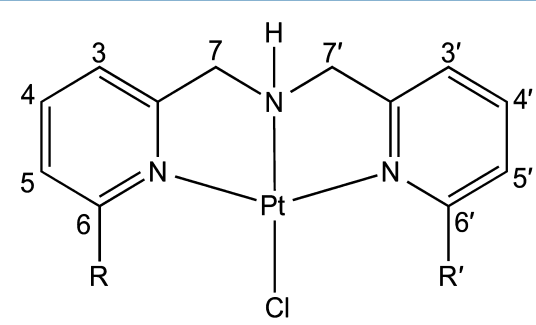

$L^{\text {tri }}$ $\mathrm{R} \quad \mathrm{R}^{\prime}$

$N(\mathrm{H}) 6,6^{\prime}-\mathrm{Me}_{2} \mathrm{dpa}$ $\mathrm{CH}_{3} \quad \mathrm{CH}_{3}$

$N(H)$ dpa

$\mathrm{H}$

$\mathrm{H}$

Figure 2. Numbering scheme for $\left[\mathrm{Pt}\left(\mathrm{N}(\mathrm{H}) 6,6^{\prime}-\mathrm{Me}_{2} \mathrm{dpa}\right) \mathrm{Cl}\right]^{+}$and $[\mathrm{Pt}(\mathrm{N}(\mathrm{H}) \mathrm{dpa}) \mathrm{Cl}]^{+}$.

adducts with several G derivatives [e.g., 9-ethylguanine (9EtG), $5^{\prime}$-guanonsine monophosphate ( $5^{\prime}$-GMP), etc..$^{23}$ In such adducts, the guanine base has two orientations with respect to the coordination plane, leading to the presence of syn and anti rotamers (Figure 3), which can interconvert by rotation about the $\mathrm{Pt}-\mathrm{N} 7$ bond. As shown in the figure, the rotamer with the $\mathrm{H}$ atom of the central $\mathrm{N}-\mathrm{H}$ group and the guanine $\mathrm{O} 6$ on the same side of the coordination plane is
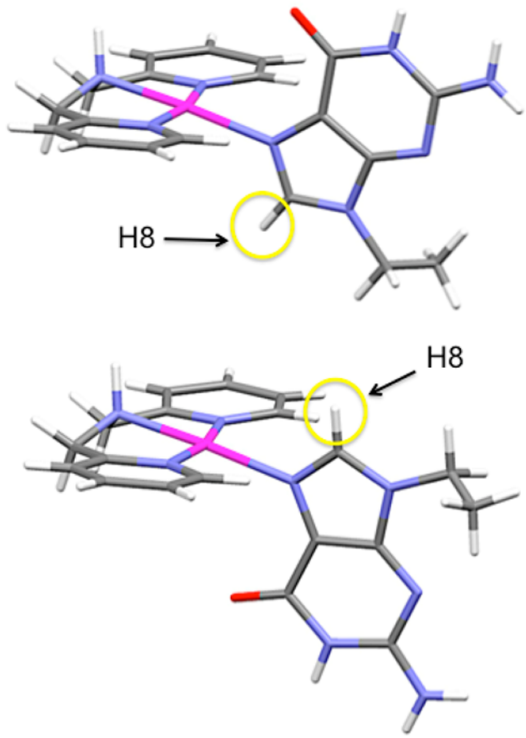

Figure 3. Two possible rotamers (syn, top; anti, bottom) for $\mathrm{Pt}\left(\mathrm{L}^{\mathrm{tri}}\right) \mathrm{G}$ complexes with tridentate ligands unsymmetrical with respect to the coordination plane but symmetrical about a plane perpendicular to the coordination plane are illustrated for $\mathrm{L}^{\text {tri }}=N(\mathrm{H}) \mathrm{dpa}$ and $\mathbf{G}=9$-EtG. The H8 proton of 9-EtG is highlighted with yellow circles. Protons in the chelate ligand $\mathrm{N}-\mathrm{CH}_{2}$ groups are called exo if they project up toward the $\mathrm{NH}$ and endo if they project down and away from the $\mathrm{NH}$.

designated as syn, and the rotamer with these groups on opposite sides of this plane is designated as anti. ${ }^{23,37}$ For all $\mathrm{Pt}(\mathrm{N}(\mathrm{H}) \mathrm{dpa}) \mathrm{G}$ adducts studied, each rotamer showed a sharp ${ }^{1} \mathrm{H}$ NMR G H8 signal, indicating that guanine base rotation about the $\mathrm{Pt}-\mathrm{N} 7$ bond was impeded by the tridentate ligand bulk. $^{23}$

In the present study, we examine $\mathrm{Pt}\left(\mathrm{L}^{\text {tri }}\right) \mathrm{G}$ adducts formed from $\left[\mathrm{Pt}\left(\mathrm{L}^{\text {tri }}\right) \mathrm{Cl}\right] \mathrm{Cl}$ (Figure 2) with $\mathrm{L}^{\text {tri }}$ possessing in-plane bulk greater than that of $N(\mathrm{H})$ dpa by introducing methyl groups at the $6 / 6^{\prime}$ positions, namely, $\mathrm{L}^{\text {tri }}=\mathrm{N}(\mathrm{H}) 6,6^{\prime}-\mathrm{Me}_{2} \mathrm{dpa}$ (di-(6-methyl-2-picolyl)amine). The methyl substituents project in the direction of the guanine base in the $\left[\mathrm{Pt}\left(\mathrm{N}(\mathrm{H}) 6,6^{\prime}\right.\right.$ $\left.\left.\mathrm{Me}_{2} \mathrm{dpa}\right) \mathrm{G}\right]^{2+}$ adducts. We employed NMR techniques to understand the influence of increased in-plane bulk on the properties of the $\left[\mathrm{Pt}\left(\mathrm{N}(\mathrm{H}) 6,6^{\prime}-\mathrm{Me}_{2} \mathrm{dpa}\right)(9-\mathrm{EtG})\right]^{2+}$ adduct. The monoadduct was found to convert readily to the $\left[\mathrm{Pt}\left(\mathrm{N}(\mathrm{H}) 6,6^{\prime}-\mathrm{Me}_{2} \mathrm{dpa}\right)(9-\mathrm{EtG})_{2}\right]^{2+}$ bisadduct (Figure 4). This process involves an unusual transformation of the Pt-bound $N(\mathrm{H}) 6,6^{\prime}-\mathrm{Me}_{2} \mathrm{dpa}$ ligand from the tridentate to the bidentate coordination mode. Because the bidentate ligand has an asymmetric racemic secondary amine and because GMP nucleotides are chiral, we undertook a very brief study of adduct formation by $5^{\prime}$ - and $3^{\prime}$-GMP with $\left[\mathrm{Pt}\left(\mathrm{N}(\mathrm{H}) 6,6^{\prime}\right.\right.$ $\left.\left.\mathrm{Me}_{2} \mathrm{dpa}\right) \mathrm{Cl}\right] \mathrm{Cl}$. We found compelling evidence that $5^{\prime}-$ and $3^{\prime}-$ GMP also promote the unusual tridentate-to-bidentate coordination mode transformation accompanying formation of a bisadduct from the initially formed monoadduct.

\section{EXPERIMENTAL SECTION}

Starting Materials. $\mathrm{K}_{2}\left[\mathrm{PtCl}_{4}\right], 3^{\prime}$ - and $5^{\prime}$-GMP, and 9-EtG were obtained from Aldrich. cis-Pt(DMSO) ${ }_{2} \mathrm{Cl}_{2}{ }^{38}$ and $\mathrm{N}(\mathrm{H}) 6,6^{\prime}-\mathrm{Me}_{2} \mathrm{dpa}^{39}$ were synthesized as described in the literature. The ${ }^{1} \mathrm{H}$ NMR chemical shifts in $\mathrm{CDCl}_{3}$ for $\mathrm{N}(\mathrm{H}) 6,6^{\prime}-\mathrm{Me}_{2}$ dpa prepared here match the reported values. ${ }^{1} \mathrm{H}$ and ${ }^{13} \mathrm{C}$ NMR shifts assigned by $2 \mathrm{D}$ NMR methods for $N(\mathrm{H}) 6,6^{\prime}-\mathrm{Me}_{2} \mathrm{dpa}$ in a $\mathrm{D}_{2} \mathrm{O} / \mathrm{DMSO}^{-} d_{6}(64: 36)$ mixture at $\mathrm{pH} 4.1$ and 11.2 are reported in Table S1, Supporting Information. 


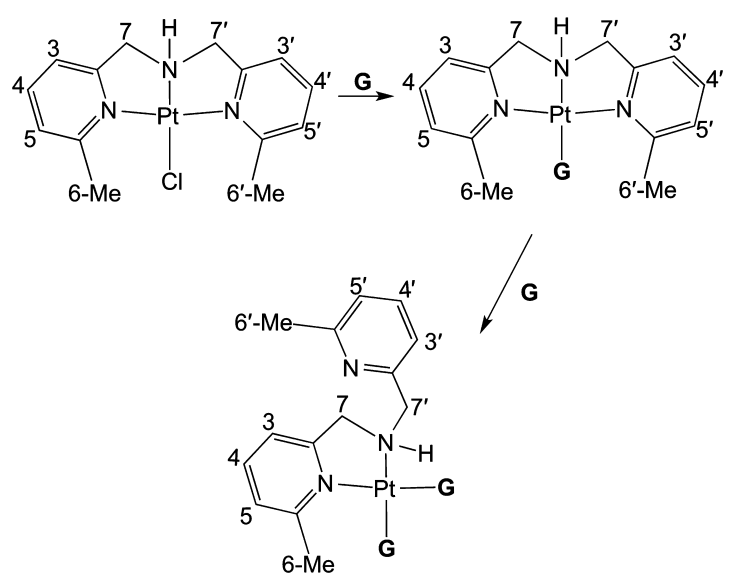

Figure 4. Transformation of the initially monofunctional complex, $\left[\mathrm{Pt}\left(\mathrm{N}(\mathrm{H}) 6,6^{\prime}-\mathrm{Me}_{2} \mathrm{dpa}\right) \mathrm{Cl}\right]^{+}$, to the bisadduct, $\left[\mathrm{Pt}\left(\mathrm{N}(\mathrm{H}) 6,6^{\prime}-\mathrm{Me}_{2} \mathrm{dpa}\right)\right.$ $\left.\mathbf{G}_{2}\right]^{2+}$, upon addition of $\mathbf{G}$. Note that the atoms in the dangling chain are designated by a prime after the number. The methylene group protons are designated as exo and endo (see text) for the chelated but not for the dangling 6-methyl-2-picolyl chains.

NMR Measurements. NMR spectra were recorded on an AvanceIII Prodigy $500 \mathrm{MHz}$ Bruker spectrometer, typically with $10 \mathrm{mM}$ samples in DMSO- $d_{6}$ or in a $\mathrm{D}_{2} \mathrm{O} / \mathrm{DMSO}-d_{6}(64: 36)$ mixture $(\mathrm{pH}$ adjusted with $0.5 \mathrm{M}$ solutions of $\mathrm{DNO}_{3}$ or $\mathrm{NaOD}$ in $\mathrm{D}_{2} \mathrm{O}$ ). For ${ }^{1} \mathrm{H}$ and ${ }^{13} \mathrm{C}$ NMR spectra in $\mathrm{D}_{2} \mathrm{O} / \mathrm{DMSO}-d_{6}$, peak positions are referenced relative to TMS by using the signals of DMSO- $d_{6}$ at 2.50 (residual) and $39.5 \mathrm{ppm}$, respectively. ${ }^{40} \mathrm{~A}$ presaturation pulse to suppress the water peak was employed when necessary. ROESY experiments were performed at $15^{\circ} \mathrm{C}$ by using a $200 \mathrm{~ms}$ mixing time. ${ }^{1} \mathrm{H}-{ }^{13} \mathrm{C}$ HSQC and HMBC NMR spectra were recorded in order to assign the signals of the adducts. NMR data were processed with TopSpin and MestreNova software. The atom-numbering system shown in Figure 2 is used in reporting or discussing ${ }^{1} \mathrm{H}$ and ${ }^{13} \mathrm{C}$ NMR data when the chelate ligand is tridentate. When the chelate ligand is bidentate, protons in the chelated 6-methyl-2-picolyl chain are labeled as $\mathrm{H} 3, \mathrm{H} 4, \mathrm{H} 5$, endo- $\mathrm{H} 7$, exo- $\mathrm{H} 7$, and 6-Me and protons in the dangling 6-methyl-2-picolyl chain are labeled as $\mathrm{H}^{\prime}, \mathrm{H}^{\prime}, \mathrm{H}^{\prime}, \mathrm{H}^{\prime}$, and $6^{\prime}$-Me (Figure 4).

X-ray Data Collection and Structure Determination. Single crystals were placed in a cooled nitrogen gas stream at $100 \mathrm{~K}$ on a Bruker Kappa Apex-II DUO diffractometer equipped with Mo K $\alpha$ radiation $(\lambda=0.71073 \AA)$. Refinement was performed by full-matrix least-squares methods using SHELXL, ${ }^{41}$ with $\mathrm{H}$ atoms in idealized positions. The $\mathrm{N}(2)$ atom of the cation in $[\mathrm{Pt}(\mathrm{N}(\mathrm{H}) \mathrm{dpa}) \mathrm{Cl}]\left[\mathrm{H}_{2} \mathrm{PO}_{4}\right]$. $\mathrm{H}_{3} \mathrm{PO}_{4} \cdot \mathrm{H}_{2} \mathrm{O}$ is disordered over two positions with occupancies of 0.485:0.515 (A:B). The cation in the $\left[\mathrm{Pt}\left(N(\mathrm{H}) 6,6^{\prime}-\mathrm{Me}_{2} \mathrm{dpa}\right) \mathrm{Cl}\right] \mathrm{Cl}$ molecule is positioned on a mirror plane, with the exception of the $\mathrm{N}(2)$ and $\mathrm{Cl}(1)$ atoms, which are out of the plane and consequently disordered over two equivalent positions.

Synthesis of $\left[\mathrm{Pt}\left(N(\mathrm{H}) 6,6^{\prime}-\mathrm{Me}_{2} \mathrm{dpa}\right) \mathrm{Cl}\right] \mathrm{Cl}$. Acetonitrile solutions of cis- $\mathrm{Pt}\left(\mathrm{Me}_{2} \mathrm{SO}\right)_{2} \mathrm{Cl}_{2}(10.6 \mathrm{mg}, 0.025 \mathrm{mmol}$ in $1 \mathrm{~mL})$ and $N(\mathrm{H}) 6,6^{\prime}-$ $\mathrm{Me}_{2}$ dpa (5.68 mg, $0.025 \mathrm{mmol}$ in $1 \mathrm{~mL}$ ) were mixed and allowed to stand at $25{ }^{\circ} \mathrm{C}$. After $2 \mathrm{~h}$, thin, yellow, X-ray quality crystals were collected on a filter and washed with acetonitrile; yield $6.85 \mathrm{mg}(56 \%)$. ${ }^{1} \mathrm{H}$ NMR signals (ppm) in DMSO- $d_{6}: 8.45(\mathrm{bs}, 1 \mathrm{H}, \mathrm{NH}), 8.03(\mathrm{t}, J=$ $\left.7.8 \mathrm{~Hz}, 2 \mathrm{H}, \mathrm{H} 4 / 4^{\prime}\right), 7.50$ (d, $\left.J=7.7 \mathrm{~Hz}, 2 \mathrm{H}, \mathrm{H} 5 / 5^{\prime}\right), 7.47$ (d, $J=7.7$ $\left.\mathrm{Hz}, 2 \mathrm{H}, \mathrm{H} 3 / 3^{\prime}\right), 5.12\left(\mathrm{dd}, J=16.1,9.1 \mathrm{~Hz}, 2 \mathrm{H}\right.$, endo- $\left.\mathrm{H} 7 / 7^{\prime}\right), 4.65$ (dd, $J=16.0,5.2 \mathrm{~Hz}, 2 \mathrm{H}$, exo- $\left.\mathrm{H} 7 / 7^{\prime}\right), 2.94\left(\mathrm{~s}, 6 \mathrm{H}, 6 / 6^{\prime}-\mathrm{CH}_{3}\right)$.

$\left[\mathrm{Pt}\left(\mathrm{N}(\mathrm{H}) 6,6^{\prime}-\mathrm{Me}_{2} \mathrm{dpa}\right)(9-\mathrm{EtG})_{2}\right]^{2+}$ Adduct. A $10 \mathrm{mM}$ solution of $\left[\mathrm{Pt}\left(\mathrm{N}(\mathrm{H}) 6,6^{\prime}-\mathrm{Me}_{2} \mathrm{dpa}\right) \mathrm{Cl}\right] \mathrm{Cl}\left[2.96 \mathrm{mg}\right.$ in $600 \mu \mathrm{L}$ of a $64: 36 \mathrm{D}_{2} \mathrm{O} /$ DMSO- $d_{6}(385 \mu \mathrm{L}: 215 \mu \mathrm{L})$ mixture] was treated with 2.5 equiv of 9EtG $(2.69 \mathrm{mg})$ to give a 1:2.5 ratio $(10 \mathrm{mM}: 25 \mathrm{mM})$ of Pt:9-EtG, and the solution $(\mathrm{pH} \approx 4)$ was kept at $25{ }^{\circ} \mathrm{C}$. (The $\mathrm{D}_{2} \mathrm{O} / \mathrm{DMSO}-d_{6}$ mixture was employed to improve the solubility of the reactants.) The reaction, which was repeated several times, was monitored by ${ }^{1} \mathrm{H}$
NMR spectroscopy until no change was observed in the bound vs free 9-EtG H8 signal intensity or until $\left[\mathrm{Pt}\left(\mathrm{N}(\mathrm{H}) 6,6^{\prime}-\mathrm{Me}_{2} \mathrm{dpa}\right)(9-\mathrm{EtG})_{2}\right]^{2+}$ adduct formation was complete, usually $\sim 4.5 \mathrm{~h}$.

RESULTS AND DISCUSSION

Structural Results. Overall Aspects. Summarized in Table 1 are the crystal data and details of the structural

Table 1. Crystal Data and Structure Refinement for $[\mathrm{Pt}(\mathrm{N}(\mathrm{H}) \mathrm{dpa}) \mathrm{Cl}]\left[\mathrm{H}_{2} \mathrm{PO}_{4}\right] \cdot \mathrm{H}_{3} \mathrm{PO}_{4} \cdot \mathrm{H}_{2} \mathrm{O}$ and $\left[\mathrm{Pt}\left(\mathrm{N}(\mathrm{H}) 6,6^{\prime}-\right.\right.$ $\left.\left.\mathrm{Me}_{2} \mathrm{dpa}\right) \mathrm{Cl}\right] \mathrm{Cl}$

\begin{tabular}{|c|c|c|}
\hline empirical formula & $\begin{array}{l}{\left[\mathrm{C}_{12} \mathrm{H}_{13} \mathrm{ClN}_{3} \mathrm{Pt}\right]\left[\mathrm{H}_{2} \mathrm{PO}_{4}\right] \cdot \mathrm{H}_{3} \mathrm{PO}_{4}} \\
\mathrm{H}_{2} \mathrm{O}\end{array}$ & {$\left[\mathrm{C}_{14} \mathrm{H}_{17} \mathrm{ClN}_{3} \mathrm{Pt}\right] \mathrm{Cl}$} \\
\hline fw & 642.79 & 493.29 \\
\hline cryst syst & triclinic & orthorhombic \\
\hline space group & $P \overline{1}$ & Pnma \\
\hline$a(\AA)$ & $6.9872(2)$ & $15.6698(9)$ \\
\hline$b(\AA)$ & $12.0630(4)$ & $6.8167(4)$ \\
\hline$c(\AA)$ & $12.8337(4)$ & $14.2516(8)$ \\
\hline$\alpha$ & $114.212(2)$ & 90 \\
\hline$\beta(\mathrm{deg})$ & $91.530(2)$ & 90 \\
\hline$\gamma$ & $102.012(2)$ & 90 \\
\hline$V\left(\AA^{3}\right)$ & $957.31(5)$ & $1522.30(15)$ \\
\hline$T(\mathrm{~K})$ & 100 & 98 \\
\hline$Z$ & 2 & 4 \\
\hline$\rho_{\text {calcd }}\left(\mathrm{Mg} / \mathrm{m}^{3}\right)$ & 2.230 & 2.152 \\
\hline abs coeff $\left(\mathrm{mm}^{-1}\right)$ & 7.69 & 9.56 \\
\hline $2 \theta_{\max }(\mathrm{deg})$ & 75.8 & 52.7 \\
\hline$R[I>2 \sigma(I)]^{a}$ & 0.032 & 0.034 \\
\hline$w R^{2 b}$ & 0.068 & 0.075 \\
\hline data/params & $10174 / 288$ & $1689 / 129$ \\
\hline res. dens $\left(\mathrm{e} \AA^{-3}\right)$ & $3.45,-1.35$ & $1.27,-1.55$ \\
\hline $\begin{array}{l}{ }^{\mathrm{R}}=\left(\sum \| F_{o} \mid\right. \\
\left.\sum^{2}\left[w\left(F_{o}^{2}\right)^{2}\right]\right]^{1 / 2} \\
\left(F_{o}^{2}+2 F_{c}^{2}\right) / 3\end{array}$ & $\left.\left|F_{c}\right| \mid\right) / \sum\left|F_{o}\right| .{ }^{b} w R^{2}=$ & $\begin{array}{l}\left.w\left(F_{o}^{2}-F_{c}^{2}\right)^{2}\right] / \\
+(\mathrm{e} P)] \text { and } P=\end{array}$ \\
\hline
\end{tabular}

refinement of $[\mathrm{Pt}(\mathrm{N}(\mathrm{H}) \mathrm{dpa}) \mathrm{Cl}]\left[\mathrm{H}_{2} \mathrm{PO}_{4}\right] \cdot \mathrm{H}_{3} \mathrm{PO}_{4} \cdot \mathrm{H}_{2} \mathrm{O}$ and $\left[\mathrm{Pt}\left(\mathrm{N}(\mathrm{H}) 6,6^{\prime}-\mathrm{Me}_{2} \mathrm{dpa}\right) \mathrm{Cl}\right] \mathrm{Cl}$. Selected bond lengths and angles are reported in Table 2. ORTEP plots of the cations of these two complexes and the numbering scheme used to describe the solid-state data are shown in Figure 5. All other references (e.g., NMR discussion) to these ligands and complexes will employ the atom-numbering scheme shown in Figure 2.

Table 2. Selected Bond Distances (Angstroms) and Angles (degrees) for $[\mathrm{Pt}(\mathrm{N}(\mathrm{H}) \mathrm{dpa}) \mathrm{Cl}]\left[\mathrm{H}_{2} \mathrm{PO}_{4}\right] \cdot \mathrm{H}_{3} \mathrm{PO}_{4} \cdot \mathrm{H}_{2} \mathrm{O}$ and $\left[\mathrm{Pt}\left(\mathrm{N}(\mathrm{H}) 6, \mathbf{6}^{\prime}-\mathrm{Me}_{2} \mathrm{dpa}\right) \mathrm{Cl}\right] \mathrm{Cl}$

$\begin{array}{lcc} & {[\mathrm{Pt}(\mathrm{N}(\mathrm{H}) \mathrm{dpa}) \mathrm{Cl}]\left[\mathrm{H}_{2} \mathrm{PO}_{4}\right] \cdot} & {\left[\mathrm{Pt}\left(\mathrm{N}(\mathrm{H}) 6,6^{\prime}-\right.\right.} \\ & \mathrm{H}_{3} \mathrm{PO}_{4} \cdot \mathrm{H}_{2} \mathrm{O} & \\ & \text { bond distances } & \\ & 2.012(2) & \\ \mathrm{Pt}-\mathrm{N}(1) & 2.014(5) & 2.048(7) \\ \mathrm{Pt}-\mathrm{N}(2) \mathrm{A} & 2.015(2) & 1.973(8) \\ \mathrm{Pt}-\mathrm{N}(3) & 2.3148(6) & 2.047(7) \\ \mathrm{Pt}-\mathrm{Cl}(1) & \text { bond angles } \\ & 166.16(8) & 2.421(3) \\ \mathrm{N}(1)-\mathrm{Pt}-\mathrm{N}(3) & 97.17(6) & \\ \mathrm{N}(1)-\mathrm{Pt}-\mathrm{Cl}(1) & 169.5(2) & 166.3(3) \\ \mathrm{N}(2) \mathrm{A}-\mathrm{Pt}-\mathrm{Cl}(1) & 96.67(6) & 95.96(18) \\ \mathrm{N}(3)-\mathrm{Pt}-\mathrm{Cl}(1) & 85.02(16) & 159.1(3) \\ \mathrm{N}(2) \mathrm{A}-\mathrm{Pt}-\mathrm{N}(1) & 81.28(16) & 95.34(18) \\ \mathrm{N}(2) \mathrm{A}-\mathrm{Pt}-\mathrm{N}(3) & & 83.2(3) \\ & & 83.4(3)\end{array}$



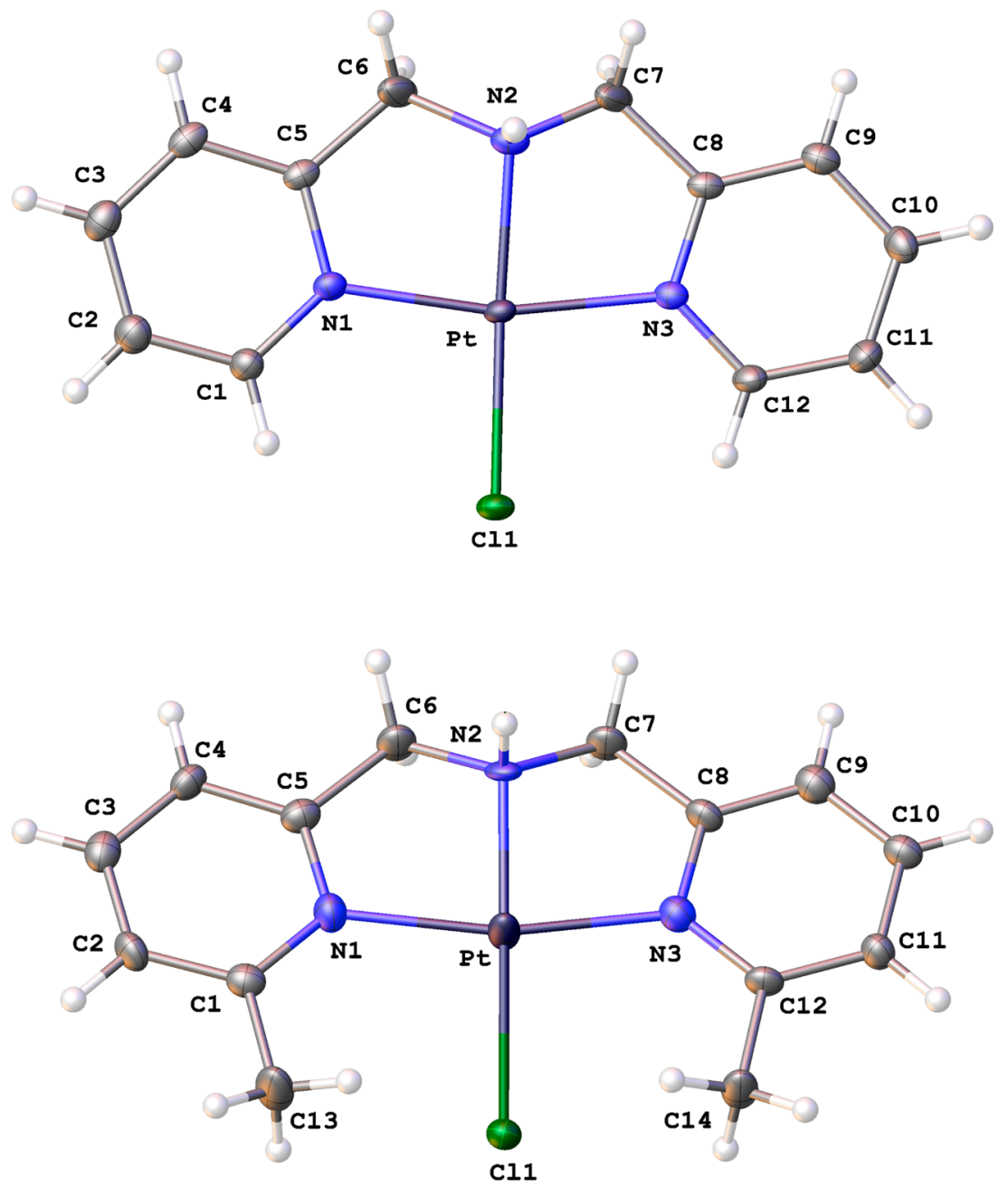

Figure 5. ORTEP plots showing the cations of $[\mathrm{Pt}(\mathrm{N}(\mathrm{H}) \mathrm{dpa}) \mathrm{Cl}]\left[\mathrm{H}_{2} \mathrm{PO}_{4}\right] \cdot \mathrm{H}_{3} \mathrm{PO}_{4} \cdot \mathrm{H}_{2} \mathrm{O}$ (top) and $\left[\mathrm{Pt}\left(\mathrm{N}(\mathrm{H}) 6,6^{\prime}-\mathrm{Me} \mathrm{dpa}_{2} \mathrm{Cl}\right] \mathrm{Cl}(\mathrm{bottom})\right.$. Thermal ellipsoids are drawn with $50 \%$ probability. Crystals are disordered, and the cation in only one of the positions is shown.

Coordination Parameters. The $\left[\mathrm{Pt}\left(\mathrm{N}(\mathrm{H}) 6,6^{\prime}-\mathrm{Me}_{2} \mathrm{dpa}\right)-\right.$ $\mathrm{Cl}^{+}$and $[\mathrm{Pt}(\mathrm{N}(\mathrm{H}) \mathrm{dpa}) \mathrm{Cl}]^{+}$cations exhibit pseudo square planar geometry, with the three $\mathrm{N}$ atoms of the tridentate ligand bound to the $\mathrm{Pt}$; a $\mathrm{Cl}$ atom trans to the $\mathrm{N}(2)$ atom completes the $\mathrm{Pt}$ coordination sphere (Figure 5). For $[\mathrm{Pt}(N(\mathrm{H}) \mathrm{dpa}) \mathrm{Cl}]^{+}$and $\left[\mathrm{Pt}\left(N(\mathrm{H}) 6,6^{\prime}-\mathrm{Me}_{2} \mathrm{dpa}\right) \mathrm{Cl}\right]^{+}$, the central $\mathrm{N}(2)$ atoms are disordered over two positions, $\mathrm{N}(2) \mathrm{A}$ and $\mathrm{N}(2) \mathrm{B}$, above and below the coordination planes, respectively. All bond lengths and angles discussed below are for the A form. Both complexes have comparable $\mathrm{N}(1)-\mathrm{Pt}-\mathrm{N}(3)$ bite angles (Table 2); these are similar to the $167.7(2)^{\circ}$ bite angle reported for $\left[\mathrm{Pt}(\mathrm{N}(\mathrm{H}) \mathrm{dpa})\left(\mathrm{OH}_{2}\right)\right]\left(\mathrm{ClO}_{4}\right)_{2} \cdot \mathrm{H}_{2} \mathrm{O}^{42}$ The $\mathrm{Pt}-\mathrm{N}(1)$ and $\mathrm{Pt}-\mathrm{N}(3)$ bond distances (Table 2) for both chloro complexes compare well with reported $\mathrm{Pt}-\mathrm{N}\left(\mathrm{sp}^{2}\right)$ bond distances ranging from 1.99 to $2.08 \AA^{43,44}$ The $\mathrm{Pt}-\mathrm{N}(2)$ bond distance for $\left[\mathrm{Pt}\left(N(\mathrm{H}) 6,6^{\prime}-\mathrm{Me}_{2} \mathrm{dpa}\right) \mathrm{Cl}\right]^{+}$is shorter than that for $[\mathrm{Pt}(N(\mathrm{H})-$ $\mathrm{dpa}) \mathrm{Cl}]^{+}$(Table 2) and for most relevant reported $\mathrm{Pt}-\mathrm{N}\left(\mathrm{sp}^{3}\right)$ bond distances $(2.01-2.12 \AA) .{ }^{45-47}$

The consequences of replacing protons on $\mathrm{C}(1)$ and $\mathrm{C}(12)$ with bulkier methyl groups are best assessed by comparing bond distances and angles in Table 2 involving the $\mathrm{Pt}-\mathrm{Cl}$ bond. The $\mathrm{N}(2)-\mathrm{Pt}-\mathrm{Cl}$ bond angle differs from $180^{\circ}$ significantly more in $\left[\mathrm{Pt}\left(\mathrm{N}(\mathrm{H}) 6,6^{\prime}-\mathrm{Me}_{2} \mathrm{dpa}\right) \mathrm{Cl}\right]^{+}\left(159.1(3)^{\circ}\right)$ than in $[\mathrm{Pt}(\mathrm{N}(\mathrm{H}) \mathrm{dpa}) \mathrm{Cl}]^{+}\left(169.5(2)^{\circ}\right)$. This large departure from $180^{\circ}$ in $\left[\mathrm{Pt}\left(\mathrm{N}(\mathrm{H}) 6,6^{\prime}-\mathrm{Me}_{2} \mathrm{dpa}\right) \mathrm{Cl}\right]^{+}$(Figure 6) arises from the

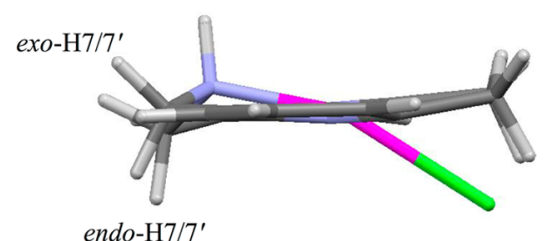

Figure 6. Orientation of the pyridyl rings in the cation of $\left[\mathrm{Pt}\left(\mathrm{N}(\mathrm{H}) 6,6^{\prime}-\mathrm{Me}_{2} \mathrm{dpa}\right) \mathrm{Cl}\right] \mathrm{Cl}$, viewed along the coordination plane and showing designations of the endo- $\mathrm{H} 7 / 7^{\prime}$ and exo- $\mathrm{H} 7 / 7^{\prime}$ protons. The figure also illustrates the large departure of the $\mathrm{N}(2)-\mathrm{Pt}-\mathrm{Cl}$ angle from $180^{\circ}$.

large steric repulsion between the coordinated $\mathrm{Cl}$ and the nearby 6/6'-Me groups. This steric interaction between the $\mathrm{Cl}$ and the Me groups results in a significantly longer $\mathrm{Pt}-\mathrm{Cl}$ bond in $\left[\mathrm{Pt}\left(\mathrm{N}(\mathrm{H}) 6,6^{\prime}-\mathrm{Me}_{2} \mathrm{dpa}\right) \mathrm{Cl}\right]^{+}$than in $[\mathrm{Pt}(\mathrm{N}(\mathrm{H}) \mathrm{dpa}) \mathrm{Cl}]^{+}$ (Table 2). This longer distance suggests that the $\mathrm{Cl}$ ligand is bound slightly more weakly in $\left[\mathrm{Pt}\left(N(\mathrm{H}) 6,6^{\prime}-\mathrm{Me}_{2} \mathrm{dpa}\right) \mathrm{Cl}\right]^{+}$than in $[\mathrm{Pt}(\mathrm{N}(\mathrm{H}) \mathrm{dpa}) \mathrm{Cl}]^{+}$. Such weaker binding may contribute to the greater reactivity toward $\mathbf{G}$ adduct formation exhibited by $\left[\mathrm{Pt}\left(\mathrm{N}(\mathrm{H}) 6,6^{\prime}-\mathrm{Me}_{2} \mathrm{dpa}\right) \mathrm{Cl}\right]^{+}$compared to $[\mathrm{Pt}(\mathrm{N}(\mathrm{H}) \mathrm{dpa}) \mathrm{Cl}]^{+}$. Furthermore, the shorter length of the $\mathrm{Pt}-\mathrm{N}$ bond is trans to $\mathrm{Cl}\left(\mathrm{Pt}-\mathrm{N}(2)\right.$, Table 2) in $\left[\mathrm{Pt}\left(\mathrm{N}(\mathrm{H}) 6,6^{\prime}-\mathrm{Me}_{2} \mathrm{dpa}\right) \mathrm{Cl}\right]^{+}$ compared to $\left[\mathrm{Pt}(\mathrm{N}(\mathrm{H}) \mathrm{dpa}) \mathrm{Cl}^{+}\right.$; this shorter bond could indicate that the $\mathrm{Cl}$ trans influence is reduced as a consequence 
of the weaker $\mathrm{Pt}-\mathrm{Cl}$ bond. The length of the $\mathrm{Pt}-\mathrm{N}(2)$ bond in $\left[\mathrm{Pt}\left(\mathrm{N}(\mathrm{H}) 6,6^{\prime}-\mathrm{Me}_{2} \mathrm{dpa}\right) \mathrm{Cl}\right]^{+}(1.973(8) \AA)$ is not significantly different from the $\mathrm{Pt}-\mathrm{N}(2)$ bond $\left(1.952(7) \AA\right.$ ) reported $^{42}$ for $\left[\mathrm{Pt}(\mathrm{N}(\mathrm{H}) \mathrm{dpa})\left(\mathrm{OH}_{2}\right)\right]\left(\mathrm{ClO}_{4}\right)_{2} \cdot \mathrm{H}_{2} \mathrm{O}$, in which the secondary amine nitrogen is trans to the aqua ligand, which has a weak trans influence.

$\left[\mathrm{Pt}\left(\mathrm{N}(\mathrm{H}) 6,6^{\prime}-\mathrm{Me}_{2} \mathrm{dpa}\right) \mathrm{Cl}\right] \mathrm{Cl}$ NMR Signal Assignments. The ${ }^{1} \mathrm{H}$ NMR signals for $\left[\mathrm{Pt}\left(\mathrm{N}(\mathrm{H}) 6,6^{\prime}-\mathrm{Me}_{2} \mathrm{dpa}\right) \mathrm{Cl}\right]^{+}$in a $64: 36 \mathrm{D}_{2} \mathrm{O} /$ DMSO- $d_{6}$ mixture are presented in Table 3 , and

Table 3. ${ }^{1} \mathrm{H}$ NMR Shifts (ppm) for $\left[\mathrm{Pt}\left(\mathrm{N}(\mathrm{H}) 6,6^{\prime}-\right.\right.$ $\left.\left.\mathrm{Me}_{2} \mathrm{dpa}\right) \mathrm{Cl}\right] \mathrm{Cl}$ and $\left[\mathrm{Pt}\left(\mathrm{N}(\mathrm{H}) 6,6^{\prime}-\mathrm{Me}_{2} \mathrm{dpa}\right)(9-\mathrm{EtG})\right]^{2+}$ in $\mathrm{D}_{2} \mathrm{O} / \mathrm{DMSO}^{-d_{6}}(\mathrm{pH} \mathrm{4.0})$ at $25^{\circ} \mathrm{C}$

\begin{tabular}{lcc}
\multicolumn{1}{c}{ proton $^{a}$} & {$\left[\mathrm{Pt}\left(\mathrm{N}(\mathrm{H}) 6,6^{\prime}-\mathrm{Me}_{2} \mathrm{dpa}\right) \mathrm{Cl}\right]$} & {$\left[\mathrm{Pt}\left(\mathrm{N}(\mathrm{H}) 6,6^{\prime}-\mathrm{Me}_{2} \mathrm{dpa}\right)(9-\right.$} \\
9-EtG H8 & $\mathrm{Cl})]^{2+}$ & $8.84^{b}, 8.54^{c}$ \\
$\mathrm{H} 4 / 4^{\prime}$ & & 7.81 \\
$\mathrm{H} 3 / 3^{\prime}$ & 7.80 & 7.31 \\
$\mathrm{H} 5 / 5^{\prime}$ & 7.23 & 7.12 \\
endo-H7/7' & 7.27 & 4.88 \\
exo-H7/7' & 4.87 & 4.50 \\
6/6'-Me & 4.47 & $2.05,^{b} 1.75^{c}$
\end{tabular}

${ }^{a}$ Free 9-EtG signals (ppm): $\mathrm{H} 8$ 7.72, $\mathrm{CH}_{2}$ 3.91, and $\mathrm{CH}_{3}$ 1.25. Bound 9-EtG signals (ppm): $\mathrm{CH}_{2} 4.10$ (anti), 4.01 (syn); $\mathrm{CH}_{3} 1.26$ (anti), 1.30 (syn). ${ }^{b}$ Signals from the anti rotamer. ${ }^{c}$ Signals from the syn rotamer.

the aromatic region is shown in Figure 7 . The equivalent $\left[\mathrm{Pt}\left(\mathrm{N}(\mathrm{H}) 6,6^{\prime}-\mathrm{Me}_{2} \mathrm{dpa}\right) \mathrm{Cl}\right]^{+}$methylene groups have equivalent carbon atoms $\left(\mathrm{C} 7\right.$ and $\left.\mathrm{C}^{\prime}\right)$, but each carbon bears inequivalent methylene protons (designated as endo- $\mathrm{H} 7 / 7^{\prime}$ and exo- $\mathrm{H} 7 / 7^{\prime}$, Figures 6 and S2, Supporting Information). The signals for the corresponding protons of the parent $[\mathrm{Pt}(\mathrm{N}(\mathrm{H}) \mathrm{dpa}) \mathrm{Cl}] \mathrm{Cl}$ complex were assigned by using the Karplus equation and the $\mathrm{H}-\mathrm{N}-\mathrm{C}-\mathrm{H}$ coupling constants measured in DMSO- $d_{6}$ (because the carrier-ligand $\mathrm{N}-\mathrm{H}$ exchanges with $\mathrm{D}_{2} \mathrm{O}$ in the $\mathrm{D}_{2} \mathrm{O} / \mathrm{DMSO}-d_{6}$ mixture). ${ }^{23}$ The $4.92 \mathrm{ppm}$ signal with the larger $\mathrm{H}-\mathrm{N}-\mathrm{C}-\mathrm{H}$ coupling constant $(8.9 \mathrm{~Hz})$ for $[\mathrm{Pt}(\mathrm{N}(\mathrm{H})$ $\mathrm{dpa}) \mathrm{Cl}]^{+}$was assigned to the endo- $\mathrm{H} 7 / 7^{\prime}$ signal because from the Karplus equation and from the $\mathrm{H}-\mathrm{N}-\mathrm{C}-\mathrm{H}$ torsion angle the endo- $\mathrm{H} 7 / 7^{\prime}$ proton would have the larger coupling constant. The exo-H7/7' signal at $4.60 \mathrm{ppm}$ has a smaller $\mathrm{H}-\mathrm{N}-\mathrm{C}-\mathrm{H}$ coupling constant $(5.1 \mathrm{~Hz})$. For $\left[\mathrm{Pt}\left(\mathrm{N}(\mathrm{H}) 6,6^{\prime}-\right.\right.$ $\left.\left.\mathrm{Me}_{2} \mathrm{dpa}\right) \mathrm{Cl}\right]^{+}$, however, the $\mathrm{H}-\mathrm{N}-\mathrm{C}-$ endo- $\mathrm{H} 7 / 7^{\prime}\left(\sim 149^{\circ}\right)$ and $\mathrm{H}-\mathrm{N}-\mathrm{C}-$ exo-H7/ $/ 7^{\prime}\left(\sim 30^{\circ}\right)$ torsion angles in the solid do not permit such a confident assignment as was made for $[\mathrm{Pt}(\mathrm{N}(\mathrm{H}) \mathrm{dpa}) \mathrm{Cl}] \mathrm{Cl}$. Nevertheless, similarities in the $\mathrm{NH}-\mathrm{CH}$ coupling constants for the two complexes in DMSO- $d_{6}$ allow us to assign the signal of $\left[\mathrm{Pt}\left(\mathrm{N}(\mathrm{H}) 6,6^{\prime}-\mathrm{Me}_{2} \mathrm{dpa}\right) \mathrm{Cl}\right] \mathrm{Cl}$ at 5.12 $\operatorname{ppm}(J=9.1 \mathrm{~Hz})$ to endo- $\mathrm{H} 7 / 7^{\prime}$ and the signal at $4.65 \mathrm{ppm}(J$ $=5.2 \mathrm{~Hz})$ to exo- $\mathrm{H} 7 / 7^{\prime}$.

From the assignments in DMSO- $d_{6}$ we can assign the following signals for $\left[\mathrm{Pt}\left(\mathrm{N}(\mathrm{H}) 6,6^{\prime}-\mathrm{Me}_{2} \mathrm{dpa}\right) \mathrm{Cl}\right] \mathrm{Cl}$ in $\mathrm{D}_{2} \mathrm{O} /$ DMSO- $d_{6}$ (64:36 mixture): the downfield $\mathrm{H} 7 / 7^{\prime}$ signal at 4.87 $\mathrm{ppm}$ to endo- $\mathrm{H} 7 / 7^{\prime}$ and the upfield signal at $4.47 \mathrm{ppm}$ to exo$\mathrm{H} 7 / 7^{\prime}$. The respective shifts in $\mathrm{D}_{2} \mathrm{O} / \mathrm{DMSO}-d_{6}$ for $[\mathrm{Pt}(\mathrm{N}(\mathrm{H})$ $\mathrm{dpa}) \mathrm{Cl}] \mathrm{Cl}$ are 4.73 and $4.49 \mathrm{ppm} .{ }^{23}$ The exo- $\mathrm{H} 7 / 7^{\prime}$ signals have very similar shifts in these two complexes, probably because the exo-H7/7' protons project away from the coordination sphere (Figures 6 and S1, Supporting Information).

In the ${ }^{1} \mathrm{H}$ NMR spectrum of $\left[\mathrm{Pt}\left(\mathrm{N}(\mathrm{H}) 6,6^{\prime}-\mathrm{Me}_{2} \mathrm{dpa}\right) \mathrm{Cl}\right]^{+}$in $\mathrm{D}_{2} \mathrm{O} / \mathrm{DMSO}_{6} d_{6}$ (64:36 mixture) the triplet at $7.80 \mathrm{ppm}$ (Figure 7) is assigned to $\mathrm{H} 4 / 4^{\prime}$, the only type of aromatic proton that can give a triplet. In a ROESY spectrum (not shown), an NOE cross-peak from the $6 / 6^{\prime}$-Me signal assigns the $\mathrm{H} 5 / 5^{\prime}$ doublet, and thus, the other doublet is assigned to $\mathrm{H} 3 / 3^{\prime}$ (Table 3). Assignments of the ${ }^{13} \mathrm{C}$ NMR signals for $\left[\mathrm{Pt}\left(\mathrm{N}(\mathrm{H}) 6,6^{\prime}-\mathrm{Me}_{2} \mathrm{dpa}\right) \mathrm{Cl}\right]^{+}$were made through an HSQC experiment (Table 4 and Figure S2, Supporting Information).
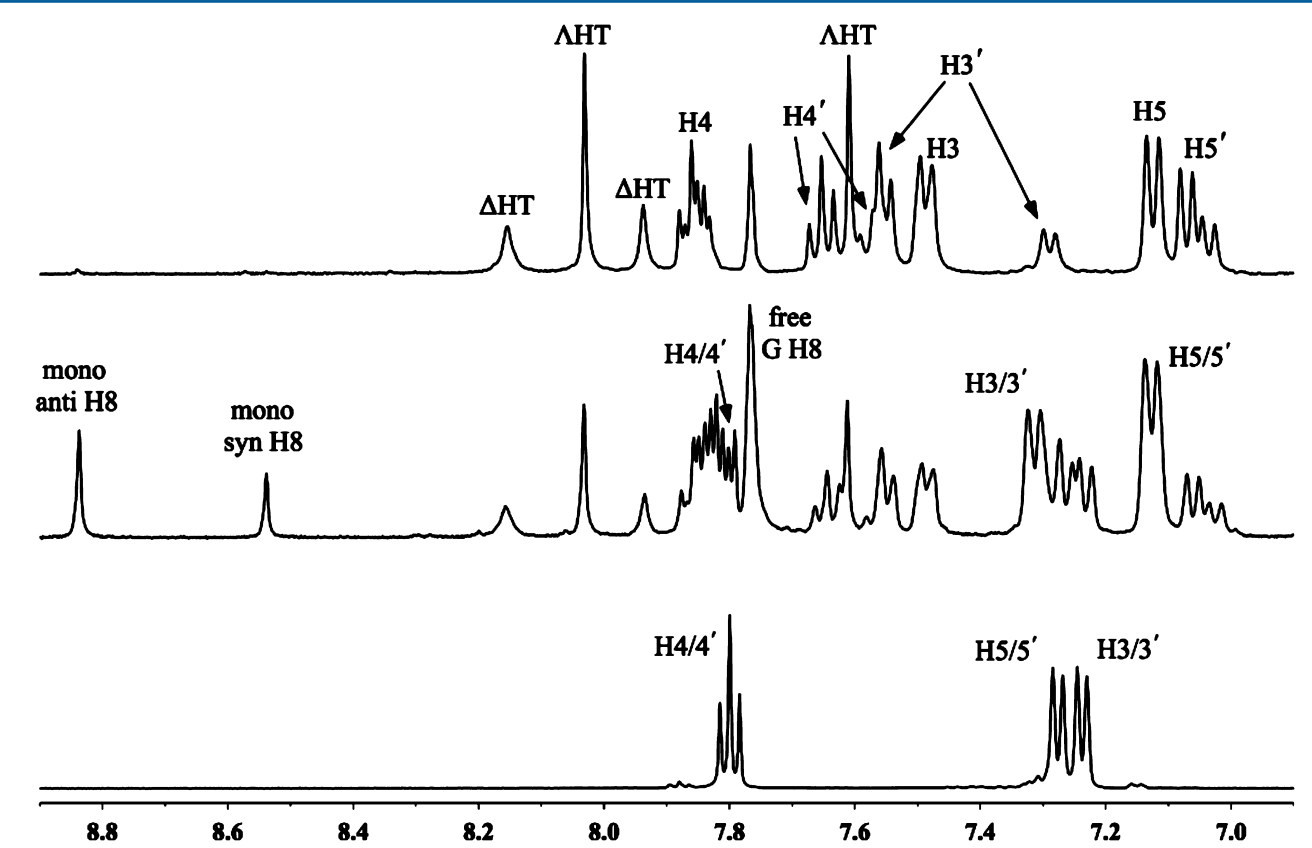

Figure 7. Aromatic region of the ${ }^{1} \mathrm{H}$ NMR spectra (shifts in ppm) of a solution of $\left[\mathrm{Pt}\left(\mathrm{N}(\mathrm{H}) 6,6^{\prime}-\mathrm{Me} \mathrm{dpa}_{2} \mathrm{Cl}\right]^{+}\left(25^{\circ} \mathrm{C}, \mathrm{D}_{2} \mathrm{O} / \mathrm{DMSO}-d_{6}\right)\right.$ before (bottom), $15 \mathrm{~min}$ after (middle), and $4.5 \mathrm{~h}$ after (top) mixing with $2.5 \mathrm{~mol}$ equiv of 9-EtG (pH 4.0). Signals for the monoadduct intermediate, $\left[\mathrm{Pt}\left(\mathrm{N}(\mathrm{H}) 6,6^{\prime}-\mathrm{Me}_{2} \mathrm{dpa}\right)(9-\mathrm{EtG})\right]^{2+}$, are labeled in the middle trace, and those for the final bis-adduct $\left[\mathrm{Pt}\left(\mathrm{N}(\mathrm{H}) 6,6^{\prime}-\mathrm{Me}_{2} \mathrm{dpa}\right)\left(9-\mathrm{EtG}_{2}\right]^{2+}\right.$ product are labeled in the top trace, where the $\Lambda \mathrm{HT}$ and $\Delta \mathrm{HT}$ labels designate the two H8 signals of each conformer. 
Table 4. ${ }^{13} \mathrm{C}$ NMR Shifts (ppm) for $\left[\operatorname{Pt}\left(N(\mathrm{H}) 6,6^{\prime}-\right.\right.$ $\left.\left.\mathrm{Me}_{2} \mathrm{dpa}\right) \mathrm{Cl}\right] \mathrm{Cl}$ and $\left[\mathrm{Pt}\left(\mathrm{N}(\mathrm{H}) 6,6^{\prime}-\mathrm{Me}_{2} \mathrm{dpa}\right)(9-\mathrm{EtG})\right]^{2+}$ in $\mathrm{D}_{2} \mathrm{O} / \mathrm{DMSO}^{-d_{6}}(\mathrm{pH} 4.0)$ at $25^{\circ} \mathrm{C}$

$\begin{array}{lcc}\text { carbon }^{a} & {\left[\mathrm{Pt}\left(\mathrm{N}(\mathrm{H}) 6,6^{\prime}-\mathrm{Me}_{2} \mathrm{dpa}\right) \mathrm{Cl}\right]} & {\left[\mathrm{Pt}\left(\mathrm{N}(\mathrm{H}) 6,6^{\prime}-\mathrm{Me}_{2} \mathrm{dpa}\right)(9-\right.} \\ \mathrm{EtG})]^{2+} & 142.6,^{b} 142.7^{c} \\ \text { 9-EtG C8 } & \mathrm{Cl} & 142.0 \\ \mathrm{C} 4 / 4^{\prime} & 142.0 & 121.2^{b} 121.1^{c} \\ \mathrm{C} 3 / 3^{\prime} & 120.6 & 128.6 \\ \mathrm{C} 5 / 5^{\prime} & 128.5 & 62.6^{b} 62.2^{c} \\ \mathrm{C} 7 / 7^{\prime} & 63.3 & 26.1,^{b} 24.8^{c} \\ 6 / 6^{\prime}-\mathrm{Me} & 27.5 & 163.9^{b} 163.8^{c} \\ \mathrm{C} 6 / 6^{\prime} & 164.8 & 167.3,^{b} 167.7^{c} \\ \mathrm{C} 2 / 2^{\prime} & 166.7 & \end{array}$

${ }^{a}$ Free 9-EtG signals (ppm): $\mathrm{C} 8$ 140.8, $\mathrm{CH}_{2}$ 40.2, and $\mathrm{CH}_{3}$ 16.3. Bound 9-EtG signals (ppm): $\mathrm{CH}_{2} 41.63$ (anti), 41.59 (syn); $\mathrm{CH}_{3} 16.4$ (anti), 16.0 (syn). ${ }^{b}$ Signals from the anti rotamer. ${ }^{c}$ Signals from the syn rotamer.

Cross-peaks (ppm) involving $\mathrm{H} 3 / 3^{\prime}$ (7.23-120.6), H4/4' (7.80-142.0), H5/5' (7.27-128.5), and 6/6' $-\mathrm{Me}(2.80-27.5)$ signals assign the $\mathrm{C} 3 / 3^{\prime}, \mathrm{C} 4 / 4^{\prime}, \mathrm{C} 5 / 5^{\prime}$, and $\mathrm{C}\left(6 / 6^{\prime}-\mathrm{Me}\right){ }^{13} \mathrm{C}$ NMR signals, respectively. Cross-peaks from the endo-H7/7' and exo-H7/7' signals assign the ${ }^{13} \mathrm{C}$ NMR signal at $63.3 \mathrm{ppm}$ to $\mathrm{C} 7 / 7^{\prime}$. Compared to the free ligand $\mathrm{C} 7 / 7^{\prime}$ shift at $52.0 \mathrm{ppm}$ (Supporting Information), the shift change of over $11 \mathrm{ppm}$ can be attributed to a combination of strain induced by chelation to $\mathrm{Pt}(\mathrm{II})$ and the $\mathrm{Pt}(\mathrm{II})$ electron-withdrawing inductive effect.

The two very downfield signals in the ${ }^{13} \mathrm{C}$ NMR spectrum of $\left[\mathrm{Pt}\left(\mathrm{N}(\mathrm{H}) 6,6^{\prime}-\mathrm{Me}_{2} \mathrm{dpa}\right) \mathrm{Cl}\right] \mathrm{Cl}$ (Figure S3, Supporting Information) do not have HSQC cross-peaks; these features are expected for $\mathrm{C} 2 / 2^{\prime}$ and $\mathrm{C} 6 / 6^{\prime}$. The shifts for these carbons attached to the pyridyl nitrogen are expected to be downfield, and they are not directly attached to a proton, accounting for the absence of an HSQC cross-peak. The $\mathrm{C} 2 / 2^{\prime}$ and $\mathrm{C} 6 / 6^{\prime}$ signals were assigned with $\mathrm{HMBC}$ cross-peaks to $\mathrm{H} 3 / 3^{\prime}$ and $\mathrm{H} 5 / 5^{\prime}$ signals (Figure S3, Supporting Information, Table 4). At $\mathrm{pH} 4.1$, the shift of the $\mathrm{C} 2 / 2^{\prime}$ signal at $166.7 \mathrm{ppm}$ is $\sim 16 \mathrm{ppm}$ more downfield than that of the free ligand at $151.1 \mathrm{ppm}$ (Table S1, Supporting Information). The results in this investigation (see below) indicate that at $\mathrm{pH} \approx 4$ a $\mathrm{C} 2 / 2^{\prime}$ shift downfield of $160 \mathrm{ppm}$ is characteristic of a bound 6methyl-2-picolyl chain, whereas a signal upfield of $155 \mathrm{ppm}$ indicates a dangling 6-methyl-2-picolyl chain.

$\left[\mathrm{Pt}\left(\mathrm{N}(\mathrm{H}) 6,6^{\prime}-\mathrm{Me}_{2} \mathrm{dpa}\right) \mathrm{Cl}\right] \mathrm{Cl}$ Adducts with 9-EtG. The reaction of $\left[\mathrm{Pt}\left(\mathrm{N}(\mathrm{H}) 6,6^{\prime}-\mathrm{Me}_{2} \mathrm{dpa}\right) \mathrm{Cl}\right] \mathrm{Cl}$ with $2.5 \mathrm{~mol}$ equiv of 9-EtG in $\mathrm{D}_{2} \mathrm{O} / \mathrm{DMSO}-d_{6}(64: 36)$ was monitored by using the H8 NMR signal of 9-EtG. At $15 \mathrm{~min}$, the spectrum (Figure 7) contained a total of six new H8 signals, and only $17 \%$ of the starting complex remained. As discussed below, two of the six new H8 signals (Figure 7) are assigned to the syn and anti rotamers (see Figure 3) of the $\left[\mathrm{Pt}\left(\mathrm{N}(\mathrm{H}) 6,6^{\prime}-\mathrm{Me}_{2} \mathrm{dpa}\right.\right.$ ) (9$\mathrm{EtG})]^{2+}$ adduct (accounting for $\sim 65 \%$ of the product). The remaining four $\mathrm{H} 8$ signals arise from a mixture of two $\left[\mathrm{Pt}\left(\mathrm{N}(\mathrm{H}) 6,6^{\prime}-\mathrm{Me}_{2} \mathrm{dpa}\right)(9-\mathrm{EtG})_{2}\right]^{2+}$ conformers. At $2.5 \mathrm{~h}$, the starting $\left[\mathrm{Pt}\left(\mathrm{N}(\mathrm{H}) 6,6^{\prime}-\mathrm{Me}_{2} \mathrm{dpa}\right) \mathrm{Cl}\right] \mathrm{Cl}$ signals had completely disappeared. In contrast, under identical conditions, complete disappearance of the starting $[\mathrm{Pt}(N(\mathrm{H}) \mathrm{dpa}) \mathrm{Cl}] \mathrm{Cl}$ signals required $\sim 49$ h. $^{23}$ The greater reactivity of $\left[\mathrm{Pt}\left(\mathrm{N}(\mathrm{H}) 6,6^{\prime}\right.\right.$ $\left.\left.\mathrm{Me}_{2} \mathrm{dpa}\right) \mathrm{Cl}\right] \mathrm{Cl}$ will be discussed below. Furthermore, the reaction of $[\mathrm{Pt}(\mathrm{N}(\mathrm{H}) \mathrm{dpa}) \mathrm{Cl}] \mathrm{Cl}$ with 9-EtG studied previously led to only the monoadduct $[\mathrm{Pt}(\mathrm{N}(\mathrm{H}) \mathrm{dpa})(9-\mathrm{EtG})]^{2+}$ (Figure $3) .^{23}$ Finally, the $\mathrm{H} 8$ signals of $\left[\mathrm{Pt}\left(\mathrm{N}(\mathrm{H}) 6,6^{\prime}-\mathrm{Me}_{2} \mathrm{dpa}\right)(9-\right.$
$\mathrm{EtG})]^{2+}$ had completely disappeared by $4.5 \mathrm{~h}$ (Figure 7 ), indicating that all of the $\left[\mathrm{Pt}\left(\mathrm{N}(\mathrm{H}) 6,6^{\prime}-\mathrm{Me}_{2} \mathrm{dpa}\right)(9-\mathrm{EtG})\right]^{2+}$ monoadduct had converted to bisadduct, $\left[\mathrm{Pt}\left(\mathrm{N}(\mathrm{H}) 6,6^{\prime}\right.\right.$ $\left.\left.\mathrm{Me}_{2} \mathrm{dpa}\right)(9-\mathrm{EtG})_{2}\right]^{2+}$, having a now bidentate chelate ligand (Figure 4).

$\left[\mathrm{Pt}\left(\mathrm{N}(\mathrm{H}) 6,6^{\prime}-\mathrm{Me}_{2} \mathrm{dpa}\right)(9-\mathrm{EtG})\right]^{2+}$ Adduct. As just mentioned, two of the six $\mathrm{H} 8$ signals observed at $15 \mathrm{~min}$ (Figure 7) are assigned to the two conformers of the monoadduct, $\left[\mathrm{Pt}\left(\mathrm{N}(\mathrm{H}) 6,6^{\prime}-\mathrm{Me}_{2} \mathrm{dpa}\right)(9-\mathrm{EtG})\right]^{2+}$. NMR spectra were recorded on fresh solutions to characterize the monoadduct because it converted to the bisadduct with time under the reaction conditions employed. Signals in the ${ }^{1} \mathrm{H}$ and ${ }^{13} \mathrm{C}$ NMR spectra for the $\left[\mathrm{Pt}\left(\mathrm{N}(\mathrm{H}) 6,6^{\prime}-\mathrm{Me}_{2} \mathrm{dpa}\right)(9-\mathrm{EtG})\right]^{2+}$ adduct (Tables 3 and 4) were assigned by using procedures similar to those detailed above for the simpler spectrum of the $\left[\mathrm{Pt}\left(\mathrm{N}(\mathrm{H}) 6,6^{\prime}-\mathrm{Me}_{2} \mathrm{dpa}\right) \mathrm{Cl}\right] \mathrm{Cl}$ complex and those described below for the more complicated spectrum of the $[\mathrm{Pt}(\mathrm{N}(\mathrm{H})$ $\left.\left.6,6^{\prime}-\mathrm{Me}_{2} \mathrm{dpa}\right)(9-\mathrm{EtG})_{2}\right]^{2+}$ adduct.

As expected from the inductive effect of $\mathrm{Pt}(\mathrm{II}),{ }^{48-50}$ the $\mathrm{H} 8$ signals at 8.84 and $8.54 \mathrm{ppm}$ are downfield of the free 9-EtG H8 signal at $7.72 \mathrm{ppm}$ (Figure 7 and Table 3). As we reported for the $[\mathrm{Pt}(\mathrm{N}(\mathrm{H}) \mathrm{dpa})(9-\mathrm{EtG})]^{2+}$ adduct, ${ }^{23}$ the tilting of the anisotropic pyridyl ring relative to the $\mathrm{Pt}(\mathrm{II})$ coordination plane positions this shielding region closer to the $\mathrm{H} 8$ proton of the syn conformer than to that of the anti conformer (Figure 3 ). The syn $\mathrm{H} 8$ signal $(8.54 \mathrm{ppm})$ is upfield relative to the anti $\mathrm{H} 8$ signal $(8.84 \mathrm{ppm})$. The shift difference between the two $\mathrm{H} 8$ signals $(\Delta \delta)$ is $\sim 0.30 \mathrm{ppm}$, a value similar to the $\Delta \delta$ of $\sim 0.33$ ppm for the $[\mathrm{Pt}(\mathrm{N}(\mathrm{H}) \mathrm{dpa})(9-\mathrm{EtG})]^{2+}$ adduct. $^{23}$

For the $\left[\mathrm{Pt}\left(\mathrm{N}(\mathrm{H}) 6,6^{\prime}-\mathrm{Me}_{2} \mathrm{dpa}\right)(9-\mathrm{EtG})\right]^{2+}$ adduct, the syn $\mathrm{H} 8$ :anti $\mathrm{H} 8$ signal intensity ratio of $1: 1.42$ indicates that the syn rotamer is less favored. In this adduct, the $6 / 6^{\prime}-\mathrm{Me}$ groups create a sterically crowded $9-\mathrm{EtG}$ coordination site. Crowding will most likely have an unfavorable effect on the syn rotamer because, as a consequence of the tilting of the pyridyl ring relative to the coordination plane, the bulky guanine sixmembered ring and the 6/6'-Me groups are on the same side of the coordination plane (Figure S4, Supporting Information). This guanine ring in the syn rotamer of $[\mathrm{Pt}(N(\mathrm{H}) \mathrm{dpa})(9-$ $\mathrm{EtG})]^{2+}$ is in a less crowded environment (A, Figure S4, Supporting Information), and the syn:anti ratio is 1.28:1, indicating that the syn rotamer is more stable.

In the syn and anti rotamers of the $\left[\mathrm{Pt}\left(\mathrm{N}(\mathrm{H}) 6,6^{\prime}\right.\right.$ $\left.\left.\mathrm{Me}_{2} \mathrm{dpa}\right)(9-\mathrm{EtG})\right]^{2+}$ adduct, guanine base canting is likely to be minimal because of steric interactions between the guanine base and the $6 / 6^{\prime}-$ Me groups. However, for the syn and anti rotamers of the $[\mathrm{Pt}(\mathrm{N}(\mathrm{H}) \mathrm{dpa})(9-\mathrm{EtG})]^{2+}$ adduct, in the absence of the bulky methyl groups, guanine base canting is likely to occur (Figure S4, Supporting Information). Canting could lead to greater shielding of $\mathrm{H} 8$ by the pyridine ring. The syn $(8.54 \mathrm{ppm})$ and anti $(8.84 \mathrm{ppm}) \mathrm{H} 8$ signals for $\left[\mathrm{Pt}\left(\mathrm{N}(\mathrm{H}) 6,6^{\prime}-\mathrm{Me}_{2} \mathrm{dpa}\right)(9-\mathrm{EtG})\right]^{2+}$ are farther downfield than the syn $(8.40 \mathrm{ppm})$ and anti $(8.73 \mathrm{ppm}) \mathrm{H} 8$ signals of $[\mathrm{Pt}(\mathrm{N}(\mathrm{H}) \mathrm{dpa})(9-\mathrm{EtG})]^{2+}{ }^{23}$ The more downfield shift of the H8 signals for the $\left[\mathrm{Pt}\left(\mathrm{N}(\mathrm{H}) 6,6^{\prime}-\mathrm{Me}_{2} \mathrm{dpa}\right)(9-\mathrm{EtG})\right]^{2+}$ rotamers may arise from a lower degree of guanine base canting (Figure S4, Supporting Information).

In a ROESY spectrum of $\left[\mathrm{Pt}\left(\mathrm{N}(\mathrm{H}) 6,6^{\prime}-\mathrm{Me}_{2} \mathrm{dpa}\right)(9-\mathrm{EtG})\right]^{2+}$ at $15{ }^{\circ} \mathrm{C}$ (Figure S5, Supporting Information), NOE crosspeaks to the assigned syn and anti $\mathrm{H} 8$ signals allow assignments of the $6 / 6^{\prime}$-Me signals at 1.75 and $2.05 \mathrm{ppm}$ to the syn and anti conformers, respectively (Table 3 ). These shifts are upfield by 1.05 and $0.75 \mathrm{ppm}$, respectively, relative to the $6 / 6^{\prime}-\mathrm{Me}$ signal 
for $\left[\mathrm{Pt}\left(\mathrm{N}(\mathrm{H}) 6,6^{\prime}-\mathrm{Me}_{2} \mathrm{dpa}\right) \mathrm{Cl}\right] \mathrm{Cl}$ (Table 3). An upfield shift is expected from the close proximity of these Me groups to the anisotropic 9-EtG base (Figure S4, Supporting Information). The more upfield shift position of the syn $6 / 6^{\prime}-\mathrm{Me}$ signal is consistent with these $6 / 6^{\prime}$-Me groups being on the same side of the coordination plane as the more shielding guanine sixmembered ring. The intensity of the H8-6/6'-Me NOE crosspeak is much lower for the syn rotamer than for the anti rotamer (Figure S5, Supporting Information), a finding consistent with the greater H8-to-6/6'-Me group distance in the syn rotamer than in the anti rotamer. This result also confirms our shift-based assignments of the syn and anti H8 signals.

The absence of H8-H8 EXSY cross-peaks in the ROESY spectrum at $15{ }^{\circ} \mathrm{C}$ of $\left[\mathrm{Pt}\left(\mathrm{N}(\mathrm{H}) 6,6^{\prime}-\mathrm{Me}_{2} \mathrm{dpa}\right)(9-\mathrm{EtG})\right]^{2+}$ (Figure S6, Supporting Information) indicates that interconversion between the rotamers is slower than for $[\mathrm{Pt}(\mathrm{N}(\mathrm{H})$ dpa)(9-EtG) $]^{2+}$, an adduct that exhibits H8-H8 EXSY crosspeaks at $15{ }^{\circ} \mathrm{C}^{23}$ Thus, as expected, the methyl groups at the $6 / 6^{\prime}$ positions of the pyridyl rings are more effective than $6 / 6^{\prime}$ protons in impeding rotation of $9-\mathrm{EtG}$ about the $\mathrm{Pt}-\mathrm{N} 7$ bond.

$\left[\mathrm{Pt}\left(\mathrm{N}(\mathrm{H}) 6,6^{\prime}-\mathrm{Me}_{2} \mathrm{dpa}\right)(\mathbf{9}-\mathrm{EtG})_{2}\right]^{2+}$ Adduct. As mentioned, four of the six product $\mathrm{H} 8$ signals (Figure 7) arise from at least two conformers of a bisadduct, $\left[\mathrm{Pt}\left(\mathrm{N}(\mathrm{H}) 6,6^{\prime}-\mathrm{Me}_{2} \mathrm{dpa}\right)(9\right.$ $\left.\mathrm{EtG})_{2}\right]^{2+}$. The two $\mathrm{H} 8$ signals of each conformer have very similar intensities, and the four bisadduct $\mathrm{H} 8$ signals are easily grouped into two pairs. The minor:major ratio of these pairs of signals remained equal to $1: 1.6$ throughout their formation, consistent with facile equilibration between the conformers. For this bisadduct to form, one 6-methyl-2-picolyl chain must be dangling and the chelate ligand must convert from a tridentate to a bidentate coordination mode (Figure 4). Before discussing the signal assignments, we note that the finding of two pairs of H8 signals maintaining a constant ratio is evidence for at least two conformers, but the situation is more complex than might appear, as discussed beginning in the next paragraph.

To explain our analysis of the two pairs of $\mathrm{H} 8$ signals, we first review the number of conformers possible for such cis bisadducts, $\mathrm{Pt}(\mathrm{N}-\mathrm{N}) \mathbf{G}_{2}$ and $\mathrm{Pt}\left(\mathrm{N}-\mathrm{N}^{\prime}\right) \mathbf{G}_{2}$ (Figure 1). When $\mathrm{N}-\mathrm{N}=$ a $C_{2}$-symmetrical achiral bidentate ligand, up to three [one $\mathrm{HH}$ and two $\mathrm{HT}(\Lambda \mathrm{HT}, \Delta \mathrm{HT})]$ rotamers may be observed in a $\mathrm{Pt}(\mathrm{N}-\mathrm{N}) \mathbf{G}_{2}$ adduct. Both $\mathbf{G}$ ligands in each conformer are equivalent if $\mathbf{G}$ lacks a chiral group (e.g., 9-EtG), and only one $\mathrm{H} 8$ signal per rotamer is possible. However, in $\mathrm{Pt}\left(\mathrm{N}-\mathrm{N}^{\prime}\right) \mathbf{G}_{2}$ adducts having an unsymmetrical achiral bidentate ligand, four rotamers ( $\mathrm{HHu}, \mathrm{HHd}, \Lambda \mathrm{HT}, \Delta \mathrm{HT}$ ) are possible (Figure 1). The $\mathbf{G}$ ligands in all conformers of such $\mathrm{Pt}\left(\mathrm{N}-\mathrm{N}^{\prime}\right) \mathbf{G}_{2}$ adducts are no longer equivalent; if $\mathbf{G}$ has either a chiral or an achiral group at N9, two H8 signals per rotamer are expected. Thus, a maximum of eight $\mathrm{H} 8$ signals could possibly be observed if all four conformers exist and all are in slow exchange. If the $\mathrm{N}-\mathrm{N}^{\prime}$ chelate ligand is both unsymmetrical and chiral and if $\mathbf{G}$ lacks a chiral group, the situation is the same, i.e., a potential maximum of eight $\mathrm{H} 8$ signals could arise for a $\mathrm{Pt}\left(\mathrm{N}-\mathrm{N}^{\prime}\right) \mathbf{G}_{2}$ adduct such as the $\left[\mathrm{Pt}\left(\mathrm{N}(\mathrm{H}) 6,6^{\prime}-\mathrm{Me}_{2} \mathrm{dpa}\right)\right.$ $\left.(9-\mathrm{EtG})_{2}\right]^{2+}$ adduct.

In $\left[\mathrm{Pt}\left(\mathrm{N}(\mathrm{H}) 6,6^{\prime}-\mathrm{Me}_{2} \mathrm{dpa}\right)(9-\mathrm{EtG})_{2}\right]^{2+}$ conformers, the bidentate ligand is unsymmetrical and the secondary nitrogen is an asymmetric center. In the perspective used in Figure 8, two configurations of the asymmetric center are possible. In one configuration, the $\mathrm{NH}$ is above the coordination plane and the dangling 6-methyl-2-picolyl chain is below the coordination plane (left sketch in Figure 8). In the other, the $\mathrm{NH}$ is below

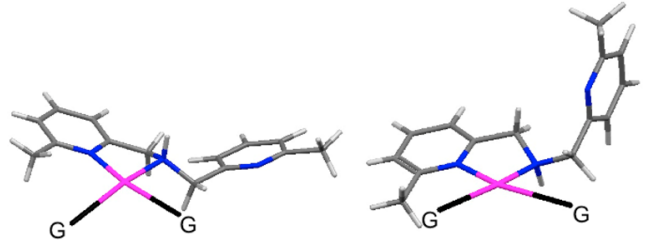

Figure 8. The two configurations of the asymmetric secondary nitrogen center of $\left[\mathrm{Pt}\left(\mathrm{N}(\mathrm{H}) 6,6^{\prime}-\mathrm{Me}_{2} \mathrm{dpa}\right) \mathbf{G}_{2}\right]^{2+}$ adducts, with the methylene group of the dangling pyridyl chain below (left) and above (right) the coordination plane. Because 9-EtG is not chiral, these two configurations are formed in equal abundance in the $\left[\mathrm{Pt}\left(\mathrm{N}(\mathrm{H}) 6,6^{\prime}-\right.\right.$ $\left.\left.\mathrm{Me}_{2} \mathrm{dpa}\right)(9-\mathrm{EtG})_{2}\right]^{2+}$ adduct. Because the HT conformers are chiral, the $\Delta \mathrm{HT}$ and $\Lambda \mathrm{HT}$ conformers with the chelate configuration on the left have equal abundance and are the mirror images of the respective $\Lambda \mathrm{HT}$ and $\Delta \mathrm{HT}$ conformers with the chelate configuration on the right. These enantiomers cannot be distinguished by typical NMR methods for adducts of $\mathbf{G}=9$-EtG. The configuration of the asymmetric center illustrated on the right is used to discuss results in this study.

the coordination plane and the dangling 6-methyl-2-picolyl chain is above the coordination plane. Because 9-EtG has no chiral group, each conformer exists as an enantiomeric pair with signals that have identical shifts for each enantiomer; hence, at most two H8 signals are expected for each conformer. Another consequence of the fact that 9-EtG lacks a chiral group is that the two configurations at the asymmetric nitrogen are formed in equal abundance. For the purposes of this article, we have chosen to depict only one configuration of the asymmetric center (the one illustrated on the right in Figure 8) in figures illustrating the $\left[\mathrm{Pt}\left(\mathrm{N}(\mathrm{H}) 6,6^{\prime}-\mathrm{Me}_{2} \mathrm{dpa}\right)(9-\mathrm{EtG})_{2}\right]^{2+} \mathrm{HT}$ conformers, such as in Figure 9.

For the $\left[\mathrm{Pt}\left(\mathrm{N}(\mathrm{H}) 6,6^{\prime}-\mathrm{Me}_{2} \mathrm{dpa}\right)(9-\mathrm{EtG})_{2}\right]^{2+}$ adduct, three H8 signals (at 8.15, 8.03, and $7.94 \mathrm{ppm}$ ) are downfield and one $\mathrm{H} 8$
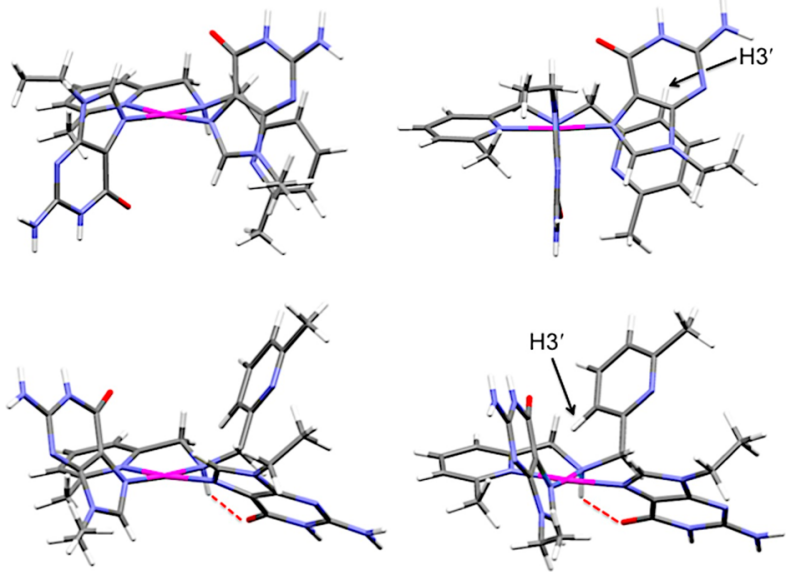

Figure 9. Possible orientations of the guanine bases in the $\Delta \mathrm{HT}$ (top) and $\Lambda \mathrm{HT}$ (bottom) conformers of $\left[\mathrm{Pt}\left(\mathrm{N}(\mathrm{H}) 6,6^{\prime}-\mathrm{Me}_{2} \mathrm{dpa}\right)(9-\mathrm{EtG})_{2}\right]^{2+}$ adducts. As illustrated, in the $\Delta \mathrm{HT}$ conformer the 9-EtG base is in close proximity to the dangling pyridyl ring; this proximity could cause the anisotropic 9-EtG base to induce a more upfield shift in the pyridyl ring signals (particularly, $\mathrm{H}^{\prime}$ ', upper right) for the $\Delta \mathrm{HT}$ conformer, as compared to the $\Lambda \mathrm{HT}$ conformer. The illustration for the $\Lambda \mathrm{HT}$ conformer depicts the canting of the 9-EtG base expected when a hydrogen bond (dashed red line) is formed between $\mathrm{O} 6$ and $\mathrm{NH}$. The canting positions the $\mathrm{H} 8$ closer to the shielding region of the sixmembered ring of the adjacent 9-EtG base. The shift of the H8 signal of the canted 9-EtG base is relatively upfield. 
signal (at $7.61 \mathrm{ppm}$ ) is actually slightly upfield from the free 9EtG H8 signal at $7.72 \mathrm{ppm}$ (Table 5). In contrast, the H8 shifts

Table 5. ${ }^{1} \mathrm{H}$ NMR Shifts (ppm) for $\left[\mathrm{Pt}\left(\mathrm{N}(\mathrm{H}) 6,6^{\prime}-\right.\right.$ $\left.\left.\mathrm{Me}_{2} \mathrm{dpa}\right)(9-\mathrm{EtG})_{2}\right]^{2+}$ in $\mathrm{D}_{2} \mathrm{O} / \mathrm{DMSO}-d_{6}(\mathrm{pH} \mathrm{4.0})$ at $25^{\circ} \mathrm{C}$

\begin{tabular}{|c|c|c|}
\hline proton $^{a}$ & $\Lambda \mathrm{HT}$ (major) & $\Delta \mathrm{HT}$ (minor) \\
\hline \multicolumn{3}{|c|}{ 9-EtG ${ }^{b}$} \\
\hline G H8 cis B & 8.03 & 8.15 \\
\hline G $\mathrm{H} 8$ cis $\mathrm{D}$ & 7.61 & 7.94 \\
\hline $\mathrm{G} \mathrm{CH}_{2}$ cis $\mathrm{B}$ & 3.84 & 3.88 \\
\hline $\mathrm{G} \mathrm{CH}_{2}$ cis D & 3.83 & 3.85 \\
\hline $\mathrm{G} \mathrm{CH}_{3}$ cis $\mathrm{B}$ & 1.11 & 1.16 \\
\hline $\mathrm{G} \mathrm{CH}_{3}$ cis $\mathrm{D}$ & 1.15 & 1.20 \\
\hline \multicolumn{3}{|c|}{$6,6^{\prime}-\mathrm{Me}_{2} \mathrm{dpa}$} \\
\hline $\mathrm{H} 4$ & 7.86 & 7.85 \\
\hline $\mathrm{H} 4^{\prime}$ & 7.65 & 7.56 \\
\hline H3 (overlapped) & 7.48 & 7.48 \\
\hline $\mathrm{H} 3^{\prime}$ & 7.55 & 7.28 \\
\hline H5 (overlapped) & 7.12 & 7.12 \\
\hline $\mathrm{H} 5^{\prime}$ & 7.07 & 7.03 \\
\hline endo-H7 & 5.00 & 5.12 \\
\hline exo-H7 & $4.57^{c}$ & $4.57^{c}$ \\
\hline $\mathrm{H} 7^{\prime}$ & $3.72,3.86^{d}$ & $3.68,3.82^{d}$ \\
\hline 6- $\mathrm{CH}_{3}$ & 1.75 & 1.88 \\
\hline $6^{\prime}-\mathrm{CH}_{3}$ & 2.15 & 2.13 \\
\hline
\end{tabular}

${ }^{a} \mathrm{G}=9$-EtG; cis $\mathrm{B}=$ signal in $\mathrm{G}$ bound cis to bound chain; cis $\mathrm{D}=$ signal in $\mathrm{G}$ bound cis to dangling chain. ${ }^{b}$ Free $9-\mathrm{EtG}^{1} \mathrm{H}$ NMR signals: $\mathrm{H} 8$ 7.72, $\mathrm{CH}_{2}$ 3.91, and $\mathrm{CH}_{3} 1.25$ ppm. ${ }^{c}$ Signals are masked by the HOD signal. ${ }^{d}$ Signals are masked by the $\mathrm{CH}_{2}$ signals of the 9-EtG ethyl group.

of the monoadduct ( 8.54 and $8.84 \mathrm{ppm}$ ) are relatively downfield. This shift pattern, which is characteristic of shifts observed on mono- vs bisadduct formation, can be attributed to the counterbalancing effects of the $\mathrm{Pt}(\mathrm{II})$ inductive effect versus the anisotropic effect of the adjacent guanine. A pattern attributable to the same effects can be seen in shifts of signals for protons on the carbon attached to the guanine N9. Thus, the shifts of the 9-EtG $\mathrm{CH}_{2}$ signal in the bisadduct (averaging $\sim 3.85 \mathrm{ppm})$ are slightly upfield of that for the free 9-EtG (3.91 $\mathrm{ppm}$ ), whereas those for the monoadduct (averaging $\sim 4.05$ ppm) are slightly downfield (Tables 3 and 5).

The four $\mathrm{H} 8$ signals of the $\left[\mathrm{Pt}\left(\mathrm{N}(\mathrm{H}) 6,6^{\prime}-\mathrm{Me}_{2} \mathrm{dpa}\right)(9\right.$ $\left.\mathrm{EtG})_{2}\right]^{2+}$ adduct can be grouped into minor ( 8.15 and 7.94 ppm) and major (8.03 and $7.61 \mathrm{ppm}$ ) pairs. These pairs are always present in a 1:1.6 ratio, as mentioned above. At this point, to simplify discussion, we state that the minor and major rotamers are the $\Delta \mathrm{HT}$ and $\Lambda \mathrm{HT}$ conformers (Figure 9), respectively, when the configuration on the right in Figure 8 is used.

Because one 6-methyl-2-picolyl chain is dangling, the corresponding protons of the two halves of the now bidentate chelate ligand are not equivalent in all $\left[\mathrm{Pt}\left(\mathrm{N}(\mathrm{H}) 6,6^{\prime}-\mathrm{Me}_{2} \mathrm{dpa}\right)\right.$ $\left.(9-\mathrm{EtG})_{2}\right]^{2+}$ conformers (Figures 4, 8, and 9). Four 6-Me signals of the adduct can be observed, and all are upfield compared to the $6 / 6^{\prime}-\mathrm{Me}$ signal of $\left[\mathrm{Pt}\left(\mathrm{N}(\mathrm{H}) 6,6^{\prime}-\mathrm{Me}_{2} \mathrm{dpa}\right) \mathrm{Cl}\right]$ $\mathrm{Cl}$ at $2.80 \mathrm{ppm}$. However, not all of the other types of chelate ligand signals can be resolved. [The aromatic and aliphatic ${ }^{1} \mathrm{H}$ NMR spectral regions for the reaction mixture forming $\left[\mathrm{Pt}\left(\mathrm{N}(\mathrm{H}) 6,6^{\prime}-\mathrm{Me}_{2} \mathrm{dpa}\right)(9-\mathrm{EtG})_{2}\right]^{2+}$ are presented in Figures 7 and S7, Supporting Information.] Two of the four Me signals [1.88 (minor, $\Delta \mathrm{HT}$ ) and 1.75 (major, $\Lambda \mathrm{HT}$ ) ppm] have upfield shifts similar to those of the syn $(1.75 \mathrm{ppm})$ and anti (2.05 ppm) 6-Me signals of the monoadduct, $\left[\mathrm{Pt}\left(\mathrm{N}(\mathrm{H}) 6,6^{\prime}\right.\right.$ $\left.\left.\mathrm{Me}_{2} \mathrm{dpa}\right)(9-\mathrm{EtG})\right]^{2+}$. These 6-Me signals of the two $[\mathrm{Pt}(\mathrm{N}(\mathrm{H})-$ $\left.\left.6,6^{\prime}-\mathrm{Me}_{2} \mathrm{dpa}\right)(9-\mathrm{EtG})_{2}\right]^{2+}$ conformers are assigned to the $6-\mathrm{Me}$ of the chelated 6-methyl-2-picolyl chain because such a 6-Me group is close to the anisotropic purine rings of the coordinated cis $9-\mathrm{EtG}$ in both the $\Delta \mathrm{HT}$ and the $\Lambda \mathrm{HT}$ conformers (Figure 9). By complementary reasoning, the downfield $6^{\prime}$-Me signals at $2.13(\Delta \mathrm{HT})$ and $2.15(\Lambda \mathrm{HT}) \mathrm{ppm}$ (Table 5), which have shifts closer to that of the $6 / 6^{\prime}$-Me signal of the free $N(\mathrm{H}) 6,6^{\prime}$ $\mathrm{Me}_{2}$ dpa ligand $(2.40 \mathrm{ppm})$, are assigned to the $6^{\prime}$-Me group in the dangling chain.

A key type of information allowing us to determine the conformations of each $\left[\mathrm{Pt}\left(\mathrm{N}(\mathrm{H}) 6,6^{\prime}-\mathrm{Me}_{2} \mathrm{dpa}\right)(9-\mathrm{EtG})_{2}\right]^{2+}$ rotamer is provided by the $\mathrm{H} 8$ signal shifts for the minor $\Delta \mathrm{HT}$ conformer (8.15 and $7.94 \mathrm{ppm}$ ) and for the major $\Lambda \mathrm{HT}$ conformer $(8.03$ and $7.61 \mathrm{ppm})$. The very upfield $7.61 \mathrm{ppm}$ shift is characteristic of the $\mathrm{H} 8$ signal of a highly canted guanine base. A high degree of guanine base canting is characteristic of a 9-EtG coordinated cis to the $\mathrm{NH}$ group of the carrier ligand with its $\mathrm{O} 6$ on the same side of the coordination plane as the $\mathrm{NH}$. The resulting O6-to-NH hydrogen bonding leads to guanine base canting. ${ }^{51}$ Canting positions the $\mathrm{H} 8$ closer to the shielding region of the six-membered ring of the adjacent guanine base (Figure 9). This positioning of $\mathrm{H} 8$ results in an upfield H8 signal for the canted 9-EtG. Such NH-to-G O6 H bonding is possible for only one HT conformer. For the $\left[\mathrm{Pt}\left(\mathrm{N}(\mathrm{H}) 6,6^{\prime}-\mathrm{Me}_{2} \mathrm{dpa}\right)(9-\mathrm{EtG})_{2}\right]^{2+}$ adduct with an unresolved asymmetric bidentate ligand, the enantiomer with the asymmetric configuration at nitrogen shown in Figure 9 has the $\Lambda \mathrm{HT}$ conformation. The guanine base of the other 9-EtG (cis to the bound pyridyl ring) in the $\Lambda \mathrm{HT}$ conformer is expected to have a low degree of canting because of the steric interaction between the guanine six-membered ring and the 6Me group. Also, this $\mathrm{H} 8$ is positioned far from the shielding region of the cis 9-EtG base (Figure 9). As a result, the H8 signal of this less canted 9-EtG base is relatively downfield at $8.03 \mathrm{ppm}$. From the foregoing it follows that the less abundant HT conformer, with H8 signals at 8.15 and $7.94 \mathrm{ppm}$, is the $\Delta \mathrm{HT}$ conformer. The lower abundance of this conformer may be a result of a steric clash of the guanine $\mathrm{O} 6$ with the dangling 6-methyl-2-picolyl chain or of the lack of any stabilizing O6-to$\mathrm{NH}$ hydrogen bonding.

For the $\left[\mathrm{Pt}\left(\mathrm{N}(\mathrm{H}) 6,6^{\prime}-\mathrm{Me}_{2} \mathrm{dpa}\right)(9-\mathrm{EtG})_{2}\right]^{2+}$ adduct, as mentioned above, the 6-Me protons of the bound pyridyl ring are close to the cis 9-EtG $\mathrm{H} 8$ in both $\left[\mathrm{Pt}\left(\mathrm{N}(\mathrm{H}) 6,6^{\prime}\right.\right.$ $\left.\left.\mathrm{Me}_{2} \mathrm{dpa}\right)(9-\mathrm{EtG})_{2}\right]^{2+}$ conformers. H8-to-6-Me NOE crosspeaks are expected from the $\mathrm{H} 8$ signals of the cis 9-EtG. H8-to$6^{\prime}$-Me NOE cross-peaks could be expected for both the $\Lambda \mathrm{HT}$ and the $\Delta \mathrm{HT}$ conformers because rotation about the bond between the asymmetric $\mathrm{N}$ and $\mathrm{CH}_{2}{ }^{\prime}$ positions the $6^{\prime}-\mathrm{Me}$ in the dangling chain close to the $\mathrm{H} 8$ of the 9-EtG cis to the secondary amine in each rotamer. However, the H8-to- $6^{\prime}-\mathrm{Me}$ NOE cross-peak should be more intense for the $\Lambda \mathrm{HT}$ rotamer because the 9-EtG $\mathrm{H} 8$ and the dangling chain are on the same side of the coordination plane. From this reasoning, we can use NOE data to assign the $\mathrm{H} 8$ and Me signals to a specific conformer. The ROESY spectrum (Figure 10) has very intense NOE cross-peaks from the $\mathrm{H} 8$ signal at $8.15 \mathrm{ppm}$ to the $6-\mathrm{Me}$ signal at $1.88 \mathrm{ppm}$ and from the $\mathrm{H} 8$ signal at $8.03 \mathrm{ppm}$ to the 6$\mathrm{Me}$ signal at $1.75 \mathrm{ppm}$. From this information we assign the $\mathrm{H} 8$ signals at 8.15 and $8.03 \mathrm{ppm}$ to the $9-\mathrm{EtG}$ cis to the chelated 6methyl-2-picolyl chain, consistent with our shift-based assign- 


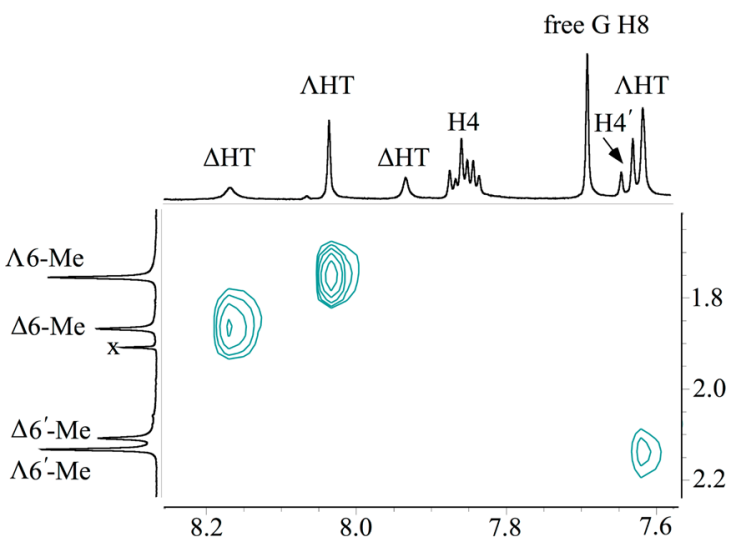

Figure 10. $\mathrm{H} 8$ and 6-Me region of the ${ }^{1} \mathrm{H}-{ }^{1} \mathrm{H}$ ROESY spectrum of the $\left[\mathrm{Pt}\left(\mathrm{N}(\mathrm{H}) 6,6^{\prime}-\mathrm{Me}_{2} \mathrm{dpa}\right)(9-\mathrm{EtG})_{2}\right]^{2+}$ adduct $\left(25^{\circ} \mathrm{C}, \mathrm{D}_{2} \mathrm{O} / \mathrm{DMSO}-\right.$ $d_{6}, \mathrm{pH} 4.0$, shifts in $\left.\mathrm{ppm}\right)$. The singlet labeled $\mathrm{X}$ at left is a solvent impurity.

ment of the signals at 1.88 and $1.75 \mathrm{ppm}$ to the 6-Me group of this chain in the two rotamers, as discussed above.

The H8 signals at 8.15 and $8.03 \mathrm{ppm}$ are connected by an EXSY cross-peak (Figure 11), confirming that the H8 signals are from the 9-EtG coordinated cis to the chelated 6-methyl-2picolyl chain in the two conformers. An EXSY cross-peak between $\mathrm{H} 8$ signals at 7.94 and $7.61 \mathrm{ppm}$ indicates that the two $\mathrm{H} 8$ signals are from the 9-EtG in the other coordination site, cis to the secondary amine. The presence of these H8-H8 EXSY cross-peaks further indicates that rotation about the $\mathrm{Pt}-\mathrm{N}$ bonds is occurring but not at a rate fast enough to average the signals of all conformers.

The H8 signal at $7.94 \mathrm{ppm}$ of the minor $\left[\mathrm{Pt}\left(\mathrm{N}(\mathrm{H}) 6,6^{\prime}\right.\right.$ $\left.\left.\mathrm{Me}_{2} \mathrm{dpa}\right)(9-\mathrm{EtG})_{2}\right]^{2+}$ rotamer does not have an NOE crosspeak to a Me signal, but the $\mathrm{H} 8$ signal of the major rotamer at $7.61 \mathrm{ppm}$ has a weak NOE cross-peak to the $6^{\prime}$-Me signal at $2.15 \mathrm{ppm}$ (Figure 10). This information allows assignment of the $6^{\prime}$-Me signals (Table 5) and also confirms that the major rotamer is the $\Lambda \mathrm{HT}$ conformer, with the $\mathrm{H} 8$ of the $9-\mathrm{EtG}$ cis to the secondary amine on the same side of the coordination plane as the dangling 6-methyl-2-picolyl chain.

As shown in Figure 1, interconversion between the two HT rotamers of the $\left[\mathrm{Pt}\left(\mathrm{N}(\mathrm{H}) 6,6^{\prime}-\mathrm{Me}_{2} \mathrm{dpa}\right)(9-\mathrm{EtG})_{2}\right]^{2+}$ adduct can pass through either one or both $\mathrm{HH}$ conformers. The 9-EtG cis to the bound chain with the 6-Me group projecting toward the guanine base would surely undergo slower rotation than would the 9-EtG adjacent to the dangling chain. If either of the two $\mathrm{HH}$ conformers existed in relatively high abundance but if the $\mathrm{HT}$-to-HH interchange were fast, separate signals for the $\mathrm{HH}$ / HT pair would not be observed. Thus, our observation of only four $\mathrm{H} 8$ signals does not rule out the presence of some of both $\mathrm{HH}$ conformers. A significant amount of an $\mathrm{HH}$ conformer could be present but not detectable in $1 \mathrm{D}$ NMR spectra; however, the $\mathrm{HH}$ conformer could be detectable in 2D NMR spectra. For example, a ROESY spectrum would contain an H8-H8 NOE cross-peak linking H8 signals from 9-EtG cis to the bound pyridyl $\mathrm{N}$ with $\mathrm{H} 8$ signals from 9-EtG cis to the dangling chain because these protons are close in both $\mathrm{HH}$ conformers (Figures 1 and S8, Supporting Information). No H8-H8 NOE cross-peak was observed for either pair of $\mathrm{H} 8$ signals (minor or major) (Figure 11), a finding consistent with a low abundance of $\mathrm{HH}$ conformers and a dominant abundance of $\Lambda \mathrm{HT}$ and $\Delta \mathrm{HT}$ conformers.

Furthermore, a low abundance of $\mathrm{HH}$ conformers of the $\left[\mathrm{Pt}\left(\mathrm{N}(\mathrm{H}) 6,6^{\prime}-\mathrm{Me}_{2} \mathrm{dpa}\right)(9-\mathrm{EtG})_{2}\right]^{2+}$ adduct is fully consistent with extensive past studies with various bidentate ligands having two $\mathrm{sp}^{2} \mathrm{~N}$ donors in heterocyclic aromatic rings or two $\mathrm{sp}^{3} \mathrm{~N}$ donors. ${ }^{20,52}$ Regardless of the type of $\mathrm{N}$ donor in the bidentate ligand, the $\mathrm{HH}$ conformer was either absent or else present in low abundance, except for adducts of guanine nucleotides that possess a phosphate group. ${ }^{26,51,53}$

To further confirm our conclusions about the conformation of the HT rotamers of $\left[\mathrm{Pt}\left(\mathrm{N}(\mathrm{H}) 6,6^{\prime}-\mathrm{Me}_{2} \mathrm{dpa}\right)(9-\mathrm{EtG})_{2}\right]^{2+}$, we assessed the effect of $\mathrm{pH}$ on conformer abundance. At high $\mathrm{pH}$, the N1H of guanine (Figure 1) becomes deprotonated, making

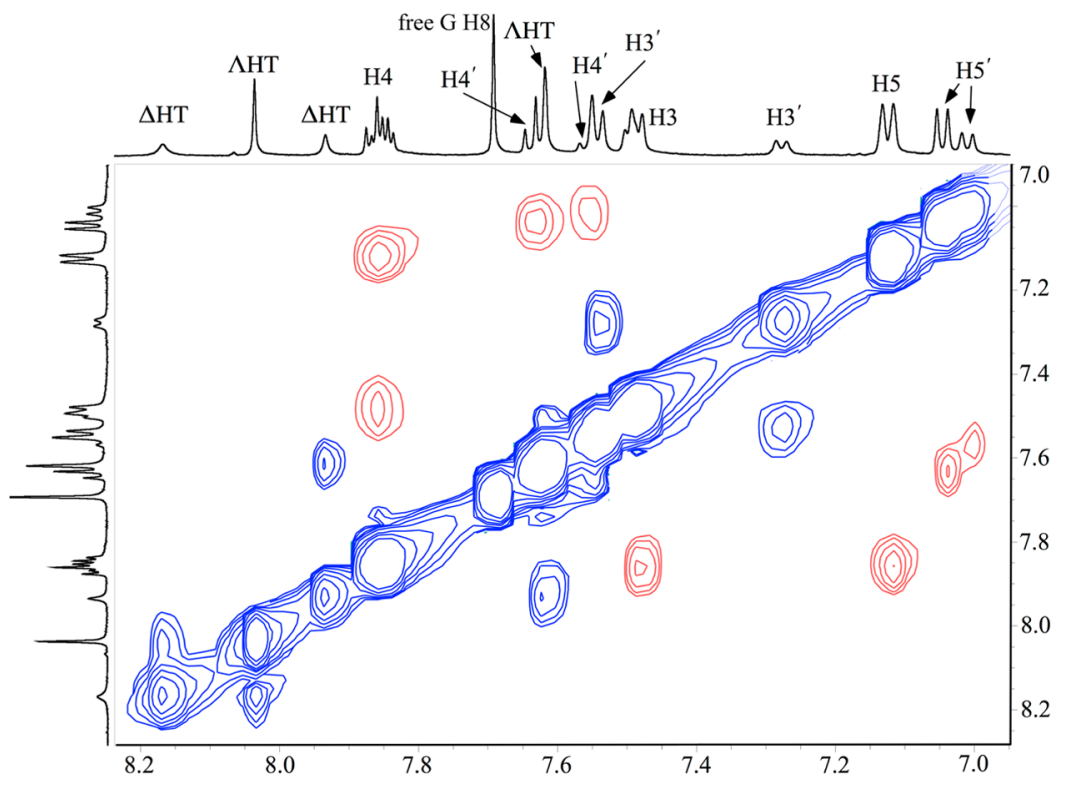

Figure 11. Aromatic region of the ${ }^{1} \mathrm{H}-{ }^{1} \mathrm{H}$ ROESY spectrum of the $\left[\mathrm{Pt}\left(\mathrm{N}(\mathrm{H}) 6,6^{\prime}-\mathrm{Me}_{2} \mathrm{dpa}\right)(9-\mathrm{EtG})_{2}\right]^{2+}\left(15{ }^{\circ} \mathrm{C}, \mathrm{D}_{2} \mathrm{O} / \mathrm{DMSO}-d_{6}\right.$, pH 4.0, shifts in ppm). The peak labeled H5 contains overlapped H5 signals of both HT rotamers. Cross-peaks shown in red are NOE cross-peaks, and those in blue are EXSY cross-peaks. 

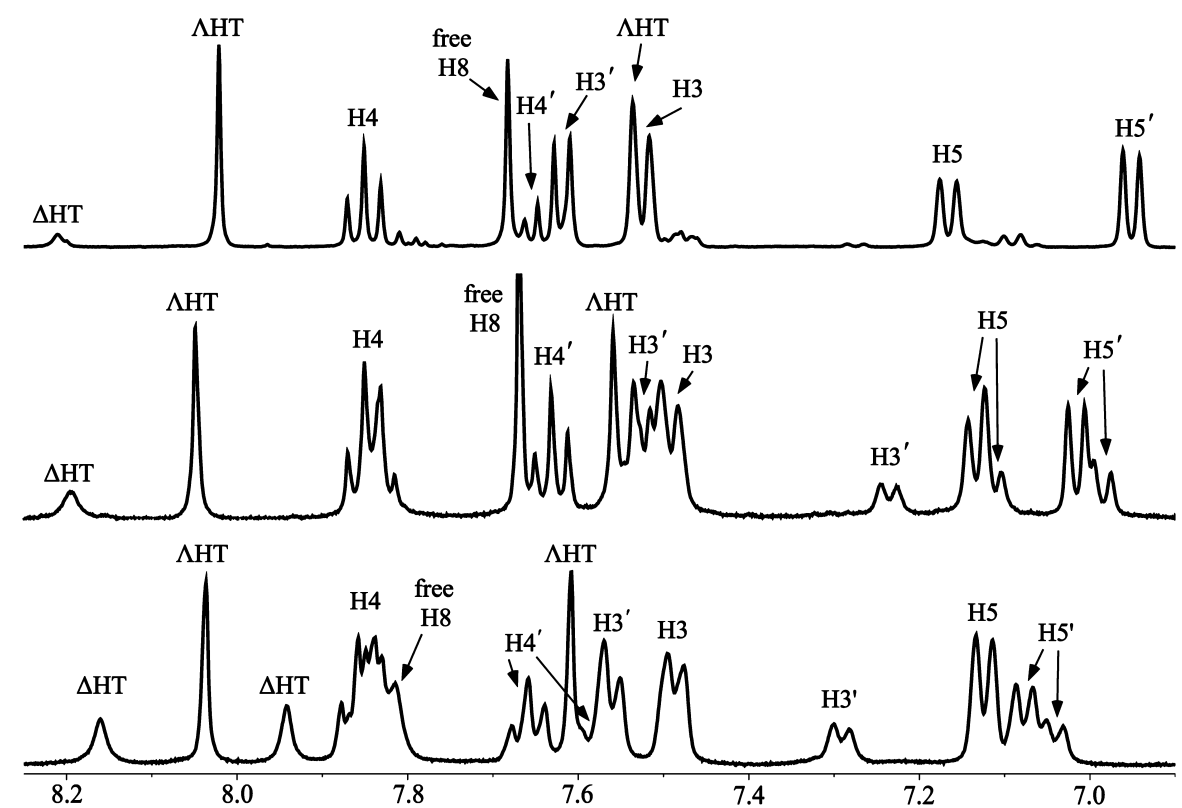

Figure 12. Aromatic region of ${ }^{1} \mathrm{H}$ NMR spectra of the $\left[\mathrm{Pt}\left(\mathrm{N}(\mathrm{H}) 6,6^{\prime}-\mathrm{Me}_{2} \mathrm{dpa}\right)(9-\mathrm{EtG})_{2}\right]^{2+}$ adduct $\left(25^{\circ} \mathrm{C}, \mathrm{D}_{2} \mathrm{O} / \mathrm{DMSO}-d_{6}\right.$, shifts in ppm $)$ at $\mathrm{pH} 4.3$ (bottom), 8.3 (middle), and 10.3 (top).

the $\mathrm{O} 6$ a stronger hydrogen bond acceptor. ${ }^{51}$ As mentioned, only the $\Lambda \mathrm{HT}$ conformer is capable of forming a $\mathrm{G}$ O6-NH hydrogen bond (Figure 9). Thus, the abundance of the $\Lambda \mathrm{HT}$ conformer is expected to increase with $\mathrm{pH}$. At low $\mathrm{pH}$ (4.3), the $\Lambda$ HT: $\Delta \mathrm{HT}$ ratio of $\left[\mathrm{Pt}\left(\mathrm{N}(\mathrm{H}) 6,6^{\prime}-\mathrm{Me}_{2} \mathrm{dpa}\right)(9-\mathrm{EtG})_{2}\right]^{2+}$ conformers was 63:37, which increased to 69:31 at $\mathrm{pH} 8.3$ and to 88:12 at $\mathrm{pH} 10.3$ (Figure 12). Thus, the $\Lambda \mathrm{HT}$ conformer (which can form an $\mathrm{O} 6-\mathrm{NH}$ hydrogen bond) has an even higher abundance than the $\Delta \mathrm{HT}$ conformer at high $\mathrm{pH}$, in agreement with previous studies of the $(\mathrm{rac})-\operatorname{BipPt}(9-$ $\mathrm{EtG})_{2}\left(\mathrm{Bip}=2,2^{\prime} \text {-bipiperidine }\right)^{20}$ and $(\mathrm{rac})-\mathrm{Me}_{2} \mathrm{DABPt}(9$ $\mathrm{EtG})_{2}\left(\mathrm{Me}_{2} \mathrm{DAB}=N, N \text {-dimethyl-2,3-diaminobutane }\right)^{21}$ adducts. For both of these adducts at high $\mathrm{pH}$ the HT conformer that can form O6-NH hydrogen bonds becomes highly favored.

Further Analysis Using NMR Data. The foregoing analysis of the $\left[\mathrm{Pt}\left(\mathrm{N}(\mathrm{H}) 6,6^{\prime}-\mathrm{Me}_{2} \mathrm{dpa}\right)(9-\mathrm{EtG})_{2}\right]^{2+}$ adduct utilized $\mathrm{H} 8$ and Me signals that are well resolved. The unusual nature of the bisadduct draws further support from ${ }^{1} \mathrm{H}$ NMR and ${ }^{13} \mathrm{C}$ NMR assignments for the carrier ligand of the $\left[\operatorname{Pt}\left(N(\mathrm{H}) 6,6^{\prime}-\mathrm{Me}_{2} \mathrm{dpa}\right)(9-\mathrm{EtG})_{2}\right]^{2+}$ adduct (Tables 5 and 6). The carrier-ligand assignments are explained here and in more detail in the Supporting Information. COSY (not shown) and HSQC and HMBC (Supporting Information, Figures S9-S12) experiments were among the NMR experiments employed. As a reminder, protons in the chelated 6-methyl-2-picolyl chain are labeled as $\mathrm{H} 3, \mathrm{H} 4, \mathrm{H} 5$, endo- $\mathrm{H} 7$, exo- $\mathrm{H} 7$, and 6-Me, and protons in the dangling 6-methyl-2-picolyl chain are labeled as $\mathrm{H} 3^{\prime}, \mathrm{H}^{\prime}, \mathrm{H}^{\prime}, \mathrm{H}^{\prime}$, and $6^{\prime}-\mathrm{Me}$ (Figure 4). This labeling scheme is also used for the ${ }^{13} \mathrm{C}$ NMR signals. Also, designations for the endo-H7, exo-H7, and $\mathrm{H}^{\prime}$ protons are shown in Figure S13 (Supporting Information).

For the $\left[\mathrm{Pt}\left(\mathrm{N}(\mathrm{H}) 6,6^{\prime}-\mathrm{Me}_{2} \mathrm{dpa}\right)(9-\mathrm{EtG})_{2}\right]^{2+}$ adduct, the shifts of the ${ }^{1} \mathrm{H}$ NMR $\left(\mathrm{H}^{\prime}{ }^{\prime}\right.$ and $\left.\mathrm{H}^{\prime}\right)$ and ${ }^{13} \mathrm{C} \mathrm{NMR}\left(\mathrm{C}^{\prime}, \mathrm{C}^{\prime}, \mathrm{C}^{\prime}\right.$, $6^{\prime}-\mathrm{Me}$, and $\left.\mathrm{C}^{\prime}\right)$ signals of the dangling chain are similar to those of the free $\mathrm{N}(\mathrm{H}) 6,6^{\prime}-\mathrm{Me}_{2} \mathrm{dpa}$ ligand (Supporting Information), evidence that a bisadduct has formed. The pyridyl ring in the dangling chain should still experience slight
Table 6. ${ }^{13} \mathrm{C}$ NMR Shifts $(\mathrm{ppm})$ for $\left[\mathrm{Pt}\left(\mathrm{N}(\mathrm{H}) 6,6^{\prime}\right.\right.$ $\left.\left.\mathrm{Me}_{2} \mathrm{dpa}\right)(9-\mathrm{EtG})_{2}\right]^{2+}$ in $\mathrm{D}_{2} \mathrm{O} / \mathrm{DMSO}-d_{6}(\mathrm{pH} 4.0)$ at $25^{\circ} \mathrm{C}$

\begin{tabular}{|c|c|c|}
\hline carbon $^{a}$ & $\Lambda \mathrm{HT}$ (major) & $\Delta \mathrm{HT}$ (minor) \\
\hline \multicolumn{3}{|c|}{ 9-EtG ${ }^{b}$} \\
\hline G $\mathrm{C} 8$ cis $\mathrm{B}$ & 142.3 & 141.5 \\
\hline G C8 cis D & 141.8 & 141.8 \\
\hline $\mathrm{G} \mathrm{CH}_{2}$ cis B (overlapped) & 41.36 & 41.42 \\
\hline $\mathrm{G} \mathrm{CH}_{2}$ cis D (overlapped) & 41.36 & 41.42 \\
\hline $\mathrm{G} \mathrm{CH}_{2}$ cis B & 15.5 & 15.6 \\
\hline $\mathrm{G} \mathrm{CH}_{2}$ cis $\mathrm{D}$ & 15.8 & 16.0 \\
\hline \multicolumn{3}{|c|}{$6,6^{\prime}-\mathrm{Me}_{2} \mathrm{dpa}$} \\
\hline C4 (overlapped) & 142.0 & 142.0 \\
\hline C4' (overlapped) & 139.8 & 139.8 \\
\hline $\mathrm{C} 3$ & 121.7 & 121.8 \\
\hline $\mathrm{C} 3^{\prime}$ & 124.0 & 123.2 \\
\hline C5 (overlapped) & 127.7 & 127.7 \\
\hline $\mathrm{C} 5^{\prime}$ & 125.0 & 124.8 \\
\hline C7 (overlapped) & 63.2 & 63.2 \\
\hline $\mathrm{C} 7^{\prime}$ & 59.5 & 59.6 \\
\hline $6-\mathrm{CH}_{3}$ & 25.0 & 24.7 \\
\hline $6^{\prime}-\mathrm{CH}_{3}$ & 24.3 & 24.4 \\
\hline $\mathrm{C} 6$ & 162.4 & 162.5 \\
\hline $\mathrm{C} 6^{\prime}$ & 159.6 & 159.5 \\
\hline $\mathrm{C} 2$ & 162.8 & 162.6 \\
\hline $\mathrm{C} 2^{\prime}$ & 153.4 & 153.3 \\
\hline
\end{tabular}

${ }^{a} \mathrm{G}=$ 9-EtG; cis $\mathrm{B}=$ signal in $\mathrm{G}$ bound cis to bound chain; cis $\mathrm{D}=$ signal in $\mathrm{G}$ bound cis to dangling chain. ${ }^{b}$ Free $9-\mathrm{EtG}^{13} \mathrm{C}$ NMR signals: C8 140.8, $\mathrm{CH}_{2} 40.2$, and $\mathrm{CH}_{3} 16.2 \mathrm{ppm}$.

inductive effects from the $\mathrm{Pt}(\mathrm{II})$ because the anchoring central nitrogen is bound. In the $\Delta \mathrm{HT}$ conformer, the proximity of the six-membered ring of the adjacent guanine base to the pyridyl ring of the dangling 6-methyl-2-picolyl chain (Figure 9) could result in slight shielding of the $\mathrm{H}^{\prime}, \mathrm{H}^{\prime}, \mathrm{H}^{\prime}$, and $6^{\prime}-\mathrm{Me}$ signals. In the $\Lambda \mathrm{HT}$ conformer, the dangling chain and the adjacent guanine six-membered ring are on opposite sides of the coordination plane (Figure 9); thus, no shielding is expected. This reasoning explains the relatively upfield shifts of 
the $\mathrm{H}^{\prime}{ }^{\prime}, \mathrm{H} 4^{\prime}, \mathrm{H} 5^{\prime}$, and $6^{\prime}-\mathrm{Me}$ signals of the $\Delta \mathrm{HT}$ conformer as compared to the corresponding signals of the $\Lambda \mathrm{HT}$ conformer (Table 5). Also, an inspection of models (Figure 9) suggests that the most likely location of the dangling chain of the $\Delta \mathrm{HT}$ conformer will position the $\mathrm{H} 3^{\prime}$ proton in the upfield-shifting region of the anisotropic guanine base, and indeed, this $\mathrm{H} 3^{\prime}$ signal does have the most upfield $\mathrm{H}^{\prime}$ ' shift (Table 5).

We now consider how the chemical shifts of the signals of $\left[\mathrm{Pt}\left(\mathrm{N}(\mathrm{H}) 6,6^{\prime}-\mathrm{Me}_{2} \mathrm{dpa}\right)(9-\mathrm{EtG})_{2}\right]^{2+}$ chelated 6-methyl-2-picolyl chain differ for the two HT conformers. The shifts of signals (H3, H4, and H5) for the bound pyridyl group are similar for the $\Lambda \mathrm{HT}$ and $\Delta \mathrm{HT}$ conformers (Table 5). These protons are far from the cis-coordinated 9-EtG base and should have signals unaffected by the guanine base orientation. As expected from the close proximity of the 6-Me group to the cis 9-EtG base (Figure 9), the 6-Me signals are upfield and have shifts similar to those of the $\left[\mathrm{Pt}\left(\mathrm{N}(\mathrm{H}) 6,6^{\prime}-\mathrm{Me}_{2} \mathrm{dpa}\right)(9-\mathrm{EtG})\right]^{2+}$ adduct (Table 3). The more upfield shift of the $1.75 \mathrm{ppm} 6-\mathrm{Me}$ signal of the $\Lambda \mathrm{HT}$ conformer of $\left[\mathrm{Pt}\left(\mathrm{N}(\mathrm{H}) 6,6^{\prime}-\mathrm{Me}_{2} \mathrm{dpa}\right)(9-\mathrm{EtG})_{2}\right]^{2+}$ compared to the $1.88 \mathrm{ppm} 6-\mathrm{Me}$ signal of the $\Delta \mathrm{HT}$ conformer (Table 5) is consistent with the expectation that the anisotropic six-membered ring of the cis-bound 9-EtG is on the same side of the coordination plane and positioned close to the 6-Me group, resulting in a greater upfield shift of this 6-Me signal. This close positioning arises from the tilting of the pyridine ring resulting from the chelate ring pucker (Figure 9). The pucker is dictated by the favored equatorial position of the dangling chain.

We report the ${ }^{13} \mathrm{C}$ NMR shifts of the $\left[\mathrm{Pt}\left(\mathrm{N}(\mathrm{H}) 6,6^{\prime}\right.\right.$ $\left.\left.\mathrm{Me}_{2} \mathrm{dpa}\right)(9-\mathrm{EtG})_{2}\right]^{2+}$ adduct in Table 6 and those for the free chelate ligand in Table S1, Supporting Information. The C7 shift (overlapped at $63.2 \mathrm{ppm}$ ) of the chelated 6-methyl-2picolyl chain is similar to that in the starting $\left[\mathrm{Pt}\left(\mathrm{N}(\mathrm{H}) 6,6^{\prime}\right.\right.$ $\left.\left.\mathrm{Me}_{2} \mathrm{dpa}\right) \mathrm{Cl}\right] \mathrm{Cl}$ complex (Table 4) and thus probably reflects strain and inductive effects as we discussed above. The $\mathrm{C7}^{\prime}$ shifts at 59.5 and $59.6 \mathrm{ppm}$ for the dangling chain of the conformers have values close to that of the free ligand, as expected for a dangling chain. Compared to the $\mathrm{C} 2 / 2^{\prime}$ shift value of the free ligand (151.1 ppm, Table S1, Supporting Information), the $\mathrm{C}^{\prime}$ signals of the dangling chains have relatively similar shifts $(\sim 153.5 \mathrm{ppm})$, whereas the $\mathrm{C} 2$ shifts $(\sim 163 \mathrm{ppm})$ of the chelated chain are quite downfield. Likewise, the overlapped $\mathrm{C}^{\prime}$ shift is close to that of the free ligand (Table S1, Supporting Information). These ${ }^{13} \mathrm{C}$ NMR data are fully consistent with the structure and properties proposed here for the $\left[\mathrm{Pt}\left(\mathrm{N}(\mathrm{H}) 6,6^{\prime}-\mathrm{Me}_{2} \mathrm{dpa}\right)(9-\mathrm{EtG})_{2}\right]^{2+}$ adduct.

Relative Reactivity of $\left[\mathrm{Pt}\left(\mathrm{N}(\mathrm{H}) 6,6^{\prime}-\mathrm{Me}_{2} \mathrm{dpa}\right) \mathrm{Cl}\right]^{+}$and $[\mathrm{Pt}(\mathrm{N}(\mathrm{H}) \mathrm{dpa}) \mathrm{Cl}]^{+}$with 9-EtG. Comparison of the times required for complete formation of $[\mathrm{Pt}(\mathrm{N}(\mathrm{H}) \mathrm{dpa})(9-\mathrm{EtG})]^{2+}$ $(\sim 49 \mathrm{~h})$ vs complete formation of $\left[\mathrm{Pt}\left(\mathrm{N}(\mathrm{H}) 6,6^{\prime}-\mathrm{Me}_{2} \mathrm{dpa}\right)(9-\right.$ $\mathrm{EtG})]^{2+}$ is complicated by the fact that the latter converts to the bisadduct on a comparable time scale. The time required for the formation of $\left[\mathrm{Pt}\left(\mathrm{N}(\mathrm{H}) 6,6^{\prime}-\mathrm{Me}_{2} \mathrm{dpa}\right)(9-\mathrm{EtG})\right]^{2+}$ is best assessed by the time needed for consumption of $\left[\mathrm{Pt}\left(\mathrm{N}(\mathrm{H}) 6,6^{\prime}-\right.\right.$ $\left.\left.\mathrm{Me}_{2} \mathrm{dpa}\right) \mathrm{Cl}\right]^{+}$. The approximate times for complete disappearance of starting $\left[\mathrm{Pt}\left(\mathrm{N}(\mathrm{H}) 6,6^{\prime}-\mathrm{Me}_{2} \mathrm{dpa}\right) \mathrm{Cl}\right]^{+}$and $[\mathrm{Pt}(\mathrm{N}(\mathrm{H})$ $\mathrm{dpa}) \mathrm{Cl}]^{+}$in $\mathrm{D}_{2} \mathrm{O} / \mathrm{DMSO}-d_{6}(64: 36)$ on addition of 2.5 equiv of 9-EtG were 2.5 and $49 \mathrm{~h}$, respectively. This order of relative reactivity is opposite to that expected from steric impedance of the attack by $9-\mathrm{EtG}$ on the $\mathrm{Pt}$ (II) centers because the tridentate $\mathrm{N}(\mathrm{H}) 6,6^{\prime}-\mathrm{Me}_{2} \mathrm{dpa}$ ligand has greater steric bulk than the tridentate $N(\mathrm{H})$ dpa ligand. The order found suggests that the dissociation of the $\mathrm{Pt}-\mathrm{N}$ (pyridyl ring) bond may be responsible for the high reactivity. Studies of $\mathrm{PtI}_{2}\left(\mathrm{Me}_{2}\right.$ phen $)$ $\left(\mathrm{Me}_{2}\right.$ phen $=2$,9-dimethyl-1,10-phenanthroline $)$ show that the steric interactions between the methyl groups of the carrier ligand and the coordinated iodides cause one end of the carrier ligand to dissociate and become monodentate, allowing a nucleophile to coordinate trans to the now monodentate $\mathrm{Me}_{2}$ phen. ${ }^{54}$ This process is promoted by the presence of a methyl group ortho to the ring $\mathrm{N}$ of $\mathrm{Me}_{2}$ phen.

A detailed kinetic and mechanistic study is outside the scope of the present work. However, we did conduct a simple set of experiments to see if dissociation of the $\mathrm{Pt}-\mathrm{N}$ (pyridyl ring) bond might be a process deserving further study in future. In order to assess if the analogous situation (a methyl group ortho to the ring $\mathrm{N}$ of $\mathrm{N}(\mathrm{H}) 6,6^{\prime}-\mathrm{Me}_{2} \mathrm{dpa}$ ) promotes dissociation of the $\mathrm{Pt}-\mathrm{N}$ (pyridyl ring) bond, concentrated $\mathrm{HCl}(10 \mu \mathrm{L})$ was added to $10 \mathrm{mM}$ solutions of $\left[\mathrm{Pt}\left(\mathrm{N}(\mathrm{H}) 6,6^{\prime}-\mathrm{Me}_{2} \mathrm{dpa}\right) \mathrm{Cl}\right]^{+}$and $[\mathrm{Pt}(\mathrm{N}(\mathrm{H}) \mathrm{dpa}) \mathrm{Cl}]^{+}$in $\mathrm{D}_{2} \mathrm{O} / \mathrm{DMSO}-d_{6}(64: 36)$. A ${ }^{1} \mathrm{H}$ NMR spectrum recorded $10 \mathrm{~min}$ after addition of $\mathrm{HCl}$ to the $\left[\mathrm{Pt}\left(\mathrm{N}(\mathrm{H}) 6,6^{\prime}-\mathrm{Me}_{2} \mathrm{dpa}\right) \mathrm{Cl}\right]^{+}$solution revealed new sets of signals (Figure S14, Supporting Information); these signals can be attributed to an intermediate with a bidentate ligand and to free protonated ligand (designated as $N(\mathrm{H}) 6,6^{\prime}-\mathrm{Me}_{2} \mathrm{dpaH}_{x}{ }^{m+}$ because the extent and the sites of protonation were not evaluated). Over time, the set of signals of the protonated free ligand, $N(\mathrm{H}) 6,6^{\prime}-\mathrm{Me}_{2} \mathrm{dpaH}_{x}{ }^{m+}$, became the most abundant. The ratio of signals for $\left[\mathrm{Pt}\left(N(\mathrm{H}) 6,6^{\prime}-\mathrm{Me}_{2} \mathrm{dpa}\right) \mathrm{Cl}\right]^{+}: N(\mathrm{H}) 6,6^{\prime}-$ $\mathrm{Me}_{2} \mathrm{dpaH}_{x}{ }^{m+}$ was $\sim 1: 1$ at $1 \mathrm{~h}$. Because formation of free ligand involves dissociation of both pyridyl rings, dissociation of one ring must require less than $1 \mathrm{~h}$. The ${ }^{1} \mathrm{H}$ NMR spectra for a $[\mathrm{Pt}(\mathrm{N}(\mathrm{H}) \mathrm{dpa}) \mathrm{Cl}]^{+}$solution under the same reaction conditions revealed no new set of signals after 1 day (Figure S15, Supporting Information) and even longer (3 days), indicating that pyridyl rings lacking a methyl group ortho to the ring $\mathrm{N}$ do not dissociate.

The results above suggest that one pyridyl ring in $\left[\mathrm{Pt}\left(\mathrm{N}(\mathrm{H}) 6,6^{\prime}-\mathrm{Me}_{2} \mathrm{dpa}\right) \mathrm{Cl}\right]^{+}$dissociates, forming a "bidentate intermediate" with the chelate having one 6-methyl-2-picolyl chain bound as part of a five-membered chelate ring and the other 6-methyl-2-picolyl chain dangling with an uncoordinated pyridyl ring N. Although overlap of one aromatic signal in the crowded region near $8.7 \mathrm{ppm}$ (Figure S14, Supporting Information) precludes the observation of all six aromatic signals expected for the "bidentate intermediate", the five signals clearly resolved integrate to the correct $1: 1$ ratio. The shifts of the ${ }^{1} \mathrm{H}$ NMR signals for the bound 6-methyl-2-picolyl chain are similar to those of the corresponding signals for $\left[\mathrm{Pt}\left(\mathrm{N}(\mathrm{H}) 6,6^{\prime}-\mathrm{Me}_{2} \mathrm{dpa}\right) \mathrm{Cl}\right]^{+}$, and the dangling 6-methyl-2picolyl chain signals are downfield because of protonation of the pyridyl ring nitrogen, as found for the free $N(\mathrm{H}) 6,6^{\prime}$ $\mathrm{Me}_{2} \mathrm{dpaH}_{x}{ }^{m+}$ ligand (shown in the top trace of Figure S14, Supporting Information). The bidentate intermediate never builds up to a high abundance, but the $\mathrm{H} 4$ triplet is readily observed downfield and undergoes informative changes in shift. The shift of the triplet is at $\sim 7.8 \mathrm{ppm}$ for $\mathrm{H} 4$ in the bound chain and at $\sim 8.3 \mathrm{ppm}$ for $\mathrm{H} 4$ in the $N(\mathrm{H}) 6,6^{\prime}-\mathrm{Me}_{2} \mathrm{dpaH}_{x}{ }^{m+}$ ligand. The bidentate intermediate has triplets at $\sim 7.9 \mathrm{ppm}$ for $\mathrm{H} 4$ in the bound chain and $\sim 8.4 \mathrm{ppm}$ for $\mathrm{H} 4$ in the dangling chain. Thus, there is clear evidence that the intermediate contains the chelate in a bidentate coordination mode.

The time required for a bidentate intermediate to form is comparable to or less than the time needed to form the $\left[\mathrm{Pt}\left(N(\mathrm{H}) 6,6^{\prime}-\mathrm{Me}_{2} \mathrm{dpa}\right)(9-\mathrm{EtG})\right]^{2+}$ adduct $(2.5 \mathrm{~h})$. Such a 
process forming this intermediate could account for the shorter time needed to form $\left[\mathrm{Pt}\left(\mathrm{N}(\mathrm{H}) 6,6^{\prime}-\mathrm{Me}_{2} \mathrm{dpa}\right)(9-\mathrm{EtG})\right]^{2+}$ than to form $[\mathrm{Pt}(\mathrm{N}(\mathrm{H}) \mathrm{dpa})(9-\mathrm{EtG})]^{2+}$. The $\mathrm{HCl}$ experiment indicates that no such reactive bidentate intermediate is formed by $[\mathrm{Pt}(\mathrm{N}(\mathrm{H}) \mathrm{dpa}) \mathrm{Cl}]^{+}$.

$\operatorname{Pt}\left(N(H) 6,6^{\prime}-M_{2}\right.$ dpa)(GMP) and $\operatorname{Pt}\left(N(H) 6,6^{\prime}-M_{2}\right.$ dpa)$(\mathrm{GMP})_{2}$ Adducts. The reaction of $\left[\mathrm{Pt}\left(\mathrm{N}(\mathrm{H}) 6,6^{\prime}-\mathrm{Me}_{2} \mathrm{dpa}\right) \mathrm{Cl}\right]$ $\mathrm{Cl}$ with $3.5 \mathrm{~mol}$ equiv of $5^{\prime}$ - or $3^{\prime}$-GMP in $\mathrm{D}_{2} \mathrm{O} / \mathrm{DMSO}-d_{6}$ (64:36) at $\mathrm{pH} 4.1$ was monitored by following the H8 NMR signal. As found for 9-EtG, these GMP nucleotides form a monoadduct that converts with time completely to a bisadduct (Figure 4). Because the charge on the GMP adducts is not known, we specify them with no brackets or charge.

Each GMP monoadduct can form at most two rotamers, as is true for the achiral 9-EtG monoadduct. A mirror plane perpendicular to the coordination plane and passing through the $\mathrm{Pt}$ and secondary $\mathrm{NH}$ group bisects the $\mathrm{Pt}\left(\mathrm{N}(\mathrm{H}) 6,6^{\prime}\right.$ $\mathrm{Me}_{2} \mathrm{dpa}$ ) moiety. Thus, the N9 chiral ribose group of the GMP's does not increase the number of rotamers for a GMP monoadduct. For both nucleotides, the $\mathrm{Pt}\left(\mathrm{N}(\mathrm{H}) 6,6^{\prime}-\mathrm{Me}_{2} \mathrm{dpa}\right)$ (GMP) monoadduct has the expected two very downfield $\mathrm{H} 8$ singlets, as shown for $\mathrm{Pt}\left(\mathrm{N}(\mathrm{H}) 6,6^{\prime}-\mathrm{Me}_{2} \mathrm{dpa}\right)\left(3^{\prime}-\mathrm{GMP}\right)$ in Figure S16, Supporting Information, and slightly downfield $\mathrm{H} 1^{\prime}$ doublets, as shown for $\mathrm{Pt}\left(\mathrm{N}(\mathrm{H}) 6,6^{\prime}-\mathrm{Me}_{2} \mathrm{dpa}\right)\left(5^{\prime}-\mathrm{GMP}\right)$ in Figure S17, Supporting Information. The chiral N9 ribose group of these nucleotides causes the corresponding protons in the two halves of the tridentate ligand to be magnetically inequivalent. In principle, four signals could be seen for each type of chelate proton, two from each of the two rotamers. However, because the ribose projects away from the chelate, the signals of such corresponding protons are usually not resolved. The ribose signals also create signal overlap problems. Nevertheless, the shifts of the $\mathrm{H} 8$ and $\mathrm{H}^{\prime}$ signals leave no doubt that two rotamers of each GMP monoadduct are formed as expected. ${ }^{23}$

For both the 5'-GMP and the $3^{\prime}$-GMP reactions, the signals of the monoadduct diminish and are fully replaced by upfieldshifted $\mathrm{H} 8$ and $\mathrm{H1}^{\prime}$ signals (Figures S16 and S17, Supporting Information), leaving no doubt that both GMP's form a $\mathrm{Pt}\left(\mathrm{N}(\mathrm{H}) 6,6^{\prime}-\mathrm{Me}_{2} \mathrm{dpa}\right)(\mathrm{GMP})_{2}$ bisadduct. In the cases of bisadducts with chiral GMP ligands or the nonchiral 9-EtG ligand, the same number of conformers (8) is possible. In contrast to the $\left[\mathrm{Pt}\left(\mathrm{N}(\mathrm{H}) 6,6^{\prime}-\mathrm{Me}_{2} \mathrm{dpa}\right)(9-\mathrm{EtG})_{2}\right]^{2+}$ adduct, which has enantiomers, the combination of the asymmetric secondary amine and the N9 chiral ribose group of GMP makes both GMP ligands in all $\mathrm{Pt}\left(\mathrm{N}(\mathrm{H}) 6,6^{\prime}-\mathrm{Me}_{2} \mathrm{dpa}\right)(\mathrm{GMP})_{2}$ conformers magnetically inequivalent. Therefore, a maximum of $16 \mathrm{H} 8$ signals could be observed if all four conformers exist and all are in slow exchange. If the rate of conformer interchange is too fast to observe $\mathrm{H} 8$ signals for the minor $\mathrm{HH}$ conformers, as found for the $\left[\mathrm{Pt}\left(\mathrm{N}(\mathrm{H}) 6,6^{\prime}-\mathrm{Me}_{2} \mathrm{dpa}\right)(9\right.$ $\left.\mathrm{EtG})_{2}\right]^{2+}$ adduct, then a maximum of eight $\mathrm{H} 8$ signals could be observed for each $\mathrm{Pt}\left(\mathrm{N}(\mathrm{H}) 6,6^{\prime}-\mathrm{Me}_{2} \mathrm{dpa}\right)(\mathrm{GMP})_{2}$ adduct. Assigning the $\mathrm{H} 8$ signals to a particular conformer and configuration of the secondary amine is not feasible, especially because aromatic NMR signals from the chelate fall in the same spectral region as the $\mathrm{H} 8$ signals. Indeed, only six of the probable eight $\mathrm{H} 8$ signals could be found for the $\mathrm{Pt}\left(\mathrm{N}(\mathrm{H}) 6,6^{\prime}\right.$ $\left.\mathrm{Me}_{2} \mathrm{dpa}\right)\left(5^{\prime} \text {-GMP }\right)_{2}$ adduct in ${ }^{1} \mathrm{H}$ NMR spectra (not shown). However, we can identify eight $\mathrm{H} 8$ signals (Figure S16, Supporting Information) from the $\operatorname{Pt}\left(\mathrm{N}(\mathrm{H}) 6,6^{\prime}-\mathrm{Me}_{2} \mathrm{dpa}\right)\left(3^{\prime}-\right.$ GMP $)_{2}$ adduct, consistent with the anticipated presence of four dominant HT conformers.
Although the ${ }^{1} \mathrm{H}$ NMR evidence for the $\operatorname{Pt}(\mathrm{N}(\mathrm{H}) 6,6$ ' $\left.\mathrm{Me}_{2} \mathrm{dpa}\right)(\mathrm{GMP})_{2}$ bisadducts is compelling, we also obtained ${ }^{13} \mathrm{C}$ NMR data supporting the existence of such adducts. For example, HSQC cross-peaks at $\sim 3.8-59.5$ ppm identify $\mathrm{C}^{\prime}$ in dangling 6-methyl-2-picolyl chains, and HSQC cross-peaks at $\sim 4.6-62.5$ and $\sim 5.0-62.5 \mathrm{ppm}$ identify $\mathrm{C} 7$ in bound chains. Thus, the overlapped ${ }^{1} \mathrm{H}$ NMR signals at $\sim 3.80 \mathrm{ppm}$ in a crowded, overlapped ${ }^{1} \mathrm{H}$ NMR spectral region for adducts of both nucleotides give HSQC cross-peaks to a ${ }^{13} \mathrm{C}$ NMR signal at 59.4 ( $5^{\prime}$-GMP) and $59.6 \mathrm{ppm}\left(3^{\prime}\right.$-GMP), assigning the dangling chain $\mathrm{C7}^{\prime}$ signals. Both GMP adducts thus have $\mathrm{C7}^{\prime}$ signals with shifts that are very similar in value to the $59.6 \mathrm{ppm}$ of the dangling chain $\mathrm{C}^{\prime}$ signal in the 9-EtG bisadduct. This similarity is further confirmation that the GMP's form a bisadduct similar to the $\left[\mathrm{Pt}\left(\mathrm{N}(\mathrm{H}) 6,6^{\prime}-\mathrm{Me}_{2} \mathrm{dpa}\right)(9-\mathrm{EtG})_{2}\right]^{2+}$ bisadduct characterized in depth above. As found with 9-EtG, the GMP nucleotides clearly transform the $N(\mathrm{H}) 6,6^{\prime}-\mathrm{Me}_{2} \mathrm{dpa}$ chelate ligand coordination mode from tridentate to bidentate.

\section{CONCLUSIONS}

The bulk of the 6/6'-Me groups of $\left[\mathrm{Pt}\left(\mathrm{N}(\mathrm{H}) 6,6^{\prime}-\mathrm{Me}_{2} \mathrm{dpa}\right) \mathrm{Cl}\right]$ $\mathrm{Cl}$ causes the chelate ligand to convert from a tridentate to a bidentate coordination mode, having one pyridyl chain dangling, facilitating coordination of 9-EtG, first to a monoadduct and then to a bisadduct. Much less time is required to form the $\left[\mathrm{Pt}\left(\mathrm{N}(\mathrm{H}) 6,6^{\prime}-\mathrm{Me}_{2} \mathrm{dpa}\right)(9-\mathrm{EtG})\right]^{2+}$ monoadduct than to form the $[\mathrm{Pt}(\mathrm{N}(\mathrm{H}) \mathrm{dpa})(9-\mathrm{EtG})]^{2+}$ monoadduct. The bulk of the methyl groups on the carrier ligand causes one of the pyridyl rings to dissociate, thus promoting faster formation of the monoadduct. Conversion to a bisadduct produces an asymmetric center at the secondary nitrogen, which for each conformer present gives rise to an enantiomeric pair having signals that cannot be resolved by ordinary NMR methods. The bulk of the 6-Me groups is sufficient to impede rotation of the guanine base about the $\mathrm{Pt}-\mathrm{N} 7$ bond of the $\left[\mathrm{Pt}\left(\mathrm{N}(\mathrm{H}) 6,6^{\prime}-\mathrm{Me}_{2} \mathrm{dpa}\right)(9-\mathrm{EtG})_{2}\right]^{2+}$ adduct; thus, $\mathrm{H} 8$ signals for conformers could be resolved and assigned. The nature of both the guanine base and the carrier ligand in the $\left[\mathrm{Pt}\left(\mathrm{N}(\mathrm{H}) 6,6^{\prime}\right.\right.$ $\left.\left.\mathrm{Me}_{2} \mathrm{dpa}\right)(9-\mathrm{EtG})_{2}\right]^{2+}$ adduct influences the distribution of conformers and their characteristics. The $\Lambda \mathrm{HT}$ conformer of $\left[\mathrm{Pt}\left(\mathrm{N}(\mathrm{H}) 6,6^{\prime}-\mathrm{Me}_{2} \mathrm{dpa}\right)(9-\mathrm{EtG})_{2}\right]^{2+}$ is more abundant than the $\Delta$ HT conformer, most probably because of the formation of a weak hydrogen bond between the $\mathrm{NH}$ of the bidentate carrier ligand and the 9-EtG O6. The 5'- and 3'-GMP nucleotides form $\mathrm{Pt}\left(\mathrm{N}(\mathrm{H}) 6,6^{\prime}-\mathrm{Me}_{2} \mathrm{dpa}\right)(\mathrm{GMP})_{2}$ adducts, in which the chelate ligand coordination mode was transformed from tridentate to bidentate.

The abundance of the syn rotamer relative to the anti rotamer is less for the $\left[\mathrm{Pt}\left(\mathrm{N}(\mathrm{H}) 6,6^{\prime}-\mathrm{Me}_{2} \mathrm{dpa}\right)(9-\mathrm{EtG})\right]^{2+}$ adduct than that reported for the $[\operatorname{Pt}(N(\mathrm{H}) \mathrm{dpa})(9-\mathrm{EtG})]^{2+}$ adduct. $^{23}$ The syn rotamer of $\left[\mathrm{Pt}\left(\mathrm{N}(\mathrm{H}) 6,6^{\prime}-\mathrm{Me}_{2} \mathrm{dpa}\right)(9\right.$ $\mathrm{EtG})]^{2+}$ is probably destabilized by steric interaction of the bulky guanine six-membered ring and the $6 / 6^{\prime}-\mathrm{Me}$ groups; these groups are on the same side of the coordination plane in the syn rotamer. We also conclude from the absence of $\mathrm{H} 8-\mathrm{H} 8$ EXSY cross-peaks for the $\left[\mathrm{Pt}\left(N(\mathrm{H}) 6,6^{\prime}-\mathrm{Me}_{2} \mathrm{dpa}\right)(9-\mathrm{EtG})\right]^{2+}$ adduct that the bulk of the methyl groups is sufficient to significantly decrease the ease of interconversion between rotamers as compared to the $[\mathrm{Pt}(\mathrm{N}(\mathrm{H}) \mathrm{dpa})(9-\mathrm{EtG})]^{2+}$ adduct, for which H8-H8 EXSY cross-peaks were observed in the previous study. ${ }^{23}$

Our study was motivated by the desire to understand the effect of steric bulk of the carrier ligand on the bound guanine 
derivative. Clearly, the $\mathrm{Pt}\left(\mathrm{N}(\mathrm{H}) 6,6^{\prime}-\mathrm{Me}_{2} \mathrm{dpa}\right)$ moiety does interact sterically with the guanine base more than the $\operatorname{Pt}(\mathrm{N}(\mathrm{H}) \mathrm{dpa})$ moiety does. However, it is also clear that the 6/6'-Me groups weaken the $\mathrm{Pt}-\mathrm{N}$ bond to such an extent that the tridentate ligand converts to a bidentate ligand. This chemistry showing the facile opening of chelate rings by nucelobase addition to $\mathrm{Pt}(\mathrm{II})$ compounds is interesting and unusual. Furthermore, our work provides a caveat: a monofunctional $\mathrm{Pt}(\mathrm{II})$ complex with bulky carrier ligands that are chelates forming $\mathrm{Pt}-\mathrm{N}$ bonds of normal length may not necessarily contain $\mathrm{Pt}-\mathrm{N}$ bonds strong enough to prevent bifunctional binding to DNA.

\section{ASSOCIATED CONTENT}

\section{S Supporting Information}

Crystallographic data for $\left[\mathrm{Pt}\left(\mathrm{N}(\mathrm{H}) 6,6^{\prime}-\mathrm{Me}_{2} \mathrm{dpa}\right) \mathrm{Cl}\right] \mathrm{Cl}$, [Pt$(\mathrm{N}(\mathrm{H}) \mathrm{dpa}) \mathrm{Cl}]\left[\mathrm{H}_{2} \mathrm{PO}_{4}\right] \cdot \mathrm{H}_{3} \mathrm{PO}_{4} \cdot \mathrm{H}_{2} \mathrm{O}$ in CIF format; preparation of $[\mathrm{Pt}(\mathrm{N}(\mathrm{H}) \mathrm{dpa}) \mathrm{Cl}]\left[\mathrm{H}_{2} \mathrm{PO}_{4}\right] \cdot \mathrm{H}_{3} \mathrm{PO}_{4} \cdot \mathrm{H}_{2} \mathrm{O}$; carrier-ligand assignments for the $\left[\mathrm{Pt}\left(\mathrm{N}(\mathrm{H}) 6,6^{\prime}-\mathrm{Me}_{2} \mathrm{dpa}\right)(9-\mathrm{EtG})_{2}\right]^{2+}$ adduct; table comparing NMR data for $\mathrm{N}(\mathrm{H}) 6,6^{\prime}-\mathrm{Me}_{2} \mathrm{dpa}$ at various $\mathrm{pH}$ values; overlap figure of the $\left[\mathrm{Pt}\left(\mathrm{N}(\mathrm{H}) 6,6^{\prime}-\mathrm{Me}_{2} \mathrm{dpa}\right) \mathrm{Cl}\right]^{+}$and $[\mathrm{Pt}(\mathrm{N}(\mathrm{H}) \mathrm{dpa}) \mathrm{Cl}]^{+}$cations; ${ }^{1} \mathrm{H}-{ }^{13} \mathrm{C}$ HSQC spectra of $[\mathrm{Pt}-$ $\left.\left(\mathrm{N}(\mathrm{H}) 6,6^{\prime}-\mathrm{Me}_{2} \mathrm{dpa}\right) \mathrm{Cl}\right] \mathrm{Cl}$ and the $\left[\mathrm{Pt}\left(\mathrm{N}(\mathrm{H}) 6,6^{\prime}-\mathrm{Me}_{2} \mathrm{dpa}\right)(9-\right.$ $\left.\mathrm{EtG})_{2}\right]^{2+}$ adduct; HMBC spectra of $\left[\mathrm{Pt}\left(\mathrm{N}(\mathrm{H}) 6,6^{\prime}-\mathrm{Me}_{2} \mathrm{dpa}\right)\right.$ $\mathrm{Cl}]^{+}$and $\left[\mathrm{Pt}\left(\mathrm{N}(\mathrm{H}) 6,6^{\prime}-\mathrm{Me}_{2} \mathrm{dpa}\right)(9-\mathrm{EtG})_{2}\right]^{2+}$ adducts; ROESY spectrum of the $\mathrm{H} 8-6-\mathrm{Me}$ and $\mathrm{H} 8-\mathrm{H} 8$ regions of the $\left[\mathrm{Pt}\left(\mathrm{N}(\mathrm{H}) 6,6^{\prime}-\mathrm{Me}_{2} \mathrm{dpa}\right)(\text { 9-EtG) }]^{2+}\right.$ adduct; ${ }^{1} \mathrm{H}$ NMR stack plot of the aliphatic region of the reaction forming $[\mathrm{Pt}(\mathrm{N}(\mathrm{H})$ $\left.\left.6,6^{\prime}-\mathrm{Me}_{2} \mathrm{dpa}\right)(9-\mathrm{EtG})\right]^{2+}$; constructed models of the syn and anti rotamers of the $[\mathrm{Pt}(\mathrm{N}(\mathrm{H}) \mathrm{dpa})(9-\mathrm{EtG})]^{2+}$ and $[\mathrm{Pt}(\mathrm{N}(\mathrm{H})$ $\left.\left.6,6^{\prime}-\mathrm{Me}_{2} \mathrm{dpa}\right)(9-\mathrm{EtG})\right]^{2+}$ adducts; constructed models of the possible $\mathrm{HH}$ conformers of the $\left[\mathrm{Pt}\left(\mathrm{N}(\mathrm{H}) 6,6^{\prime}-\mathrm{Me}_{2} \mathrm{dpa}\right)(9\right.$ EtG $\left.)_{2}\right]^{2+}$ adduct; constructed model of the bisadduct, Pt$\left(\mathrm{N}(\mathrm{H}) 6,6^{\prime}-\mathrm{Me}_{2} \mathrm{dpa}\right)(\mathbf{G})_{2}$, designating endo- $\mathrm{H} 7$, exo- $\mathrm{H} 7$, and $\mathrm{H} 7{ }^{\prime}$ protons; ${ }^{1} \mathrm{H}$ NMR stack plots of $\left[\mathrm{Pt}\left(\mathrm{N}(\mathrm{H}) 6,6^{\prime}-\mathrm{Me}_{2} \mathrm{dpa}\right)\right.$ $\mathrm{Cl}]^{+}$and $[\mathrm{Pt}(\mathrm{N}(\mathrm{H}) \mathrm{dpa}) \mathrm{Cl}]^{+}$after addition of $\mathrm{HCl} ;{ }^{1} \mathrm{H} \mathrm{NMR}$ stack plots of the aromatic region of the reaction forming $\operatorname{Pt}\left(\mathrm{N}(\mathrm{H}) 6,6^{\prime}-\mathrm{Me}_{2} \mathrm{dpa}\right)\left(3^{\prime}-\mathrm{GMP}\right)_{2}$ and of the $\mathrm{H1}^{\prime}$ and $6 / 6^{\prime}-\mathrm{Me}$ regions of the $\mathrm{Pt}\left(\mathrm{N}(\mathrm{H}) 6,6^{\prime}-\mathrm{Me}_{2} \mathrm{dpa}\right)\left(5^{\prime}-\mathrm{GMP}\right)_{2}$ adduct. This material is available free of charge via the Internet at http:// pubs.acs.org.

\section{AUTHOR INFORMATION}

\section{Corresponding Author}

*Phone: 225-578-0933. Fax: 225-578-8618. E-mail: 1marzil@ lsu.edu.

\section{Notes}

The authors declare no competing financial interest.

\section{ACKNOWLEDGMENTS}

Upgrade of the diffractometer was made possible through Grant No. LEQSF(2011-12)-ENH-TR-01, administered by the Louisiana Board of Regents.

\section{REFERENCES}

(1) Arnesano, F.; Natile, G. Coord. Chem. Rev. 2009, 253, 20702081.

(2) Jakupec, M. A.; Galanski, M.; Arion, V. B.; Hartinger, C. G.; Keppler, B. K. Dalton Trans. 2008, 183-194.

(3) Klein, A. V.; Hambley, T. W. Chem. Rev. 2009, 109, 4911-4920.

(4) Reedijk, J. Eur. J. Inorg. Chem. 2009, 2009, 1303-1312.

(5) Beljanski, V.; Villanueva, J. M.; Doetsch, P. W.; Natile, G.; Marzilli, L. G. J. Am. Chem. Soc. 2005, 127, 15833-15842.
(6) Lippert, B. Cisplatin: Chemistry and Biochemistry of a Leading Anticancer Drug; Wiley-VCH: Weinheim, 1999.

(7) Wheate, N. J.; Walker, S.; Craig, G. E.; Oun, R. Dalton Trans. 2010, 39, 8113-8127.

(8) Reedijk, J. J. Chem. Soc., Chem. Commun. 1996, 801-806.

(9) Liskova, B.; Zerzankova, L.; Novakava, O.; Kostrhunova, H.; Travnicek, Z.; Brabec, V. Chem. Res. Toxicol. 2012, 25, 500-509.

(10) Marzilli, L. G.; Saad, J. A.; Kuklenyik, Z.; Keating, K. A.; Xu, Y. J. Am. Chem. Soc. 2001, 123, 2764-2770.

(11) Ohndorf, U.-M.; Rould, M. A.; He, Q.; Pabo, C. O.; Lippard, S. J. Nature 1999, 399, 708-712.

(12) Jamieson, E. R.; Lippard, S. J. Chem. Rev. 1999, 99, 2467-2498.

(13) Todd, R. C.; Lippard, S. J. In Platinum and Other Heavy Metal Compounds in Cancer Chemotherapy; Bonetti, A., Leone, R., Muggia, F. M., Howell, S. B., Eds.; Humana Press: New York, 2009; p 67-72.

(14) Sullivan, S. T.; Saad, J. S.; Fanizzi, F. P.; Marzilli, L. G. J. Am. Chem. Soc. 2002, 124, 1558-1559.

(15) Saad, J. S.; Natile, G.; Marzilli, L. G. J. Am. Chem. Soc. 2009, 131, 12314-12324.

(16) Saad, J. A.; Benedetti, M.; Natile, G.; Marzilli, L. G. Inorg. Chem. 2010, 49, 5573-5583.

(17) Lovejoy, K. S.; Todd, R. C.; Zhang, S.; McCormick, M. S.; D’Aquino, J. A.; Reardon, J. T.; Sancar, A.; Giacomini, K. M.; Lippard, S. J. Proc. Natl. Acad. Sci. U.S.A. 2008, 105, 8902-8907.

(18) Ano, S. O.; Kuklenyik, Z.; Marzilli, L. G. In In Cisplatin: Chemistry and Biochemistry of a Leading Anticancer Drug; Lippert, B., Ed.; Wiley-VCH: Weinheim, 1999; pp 247-291.

(19) Ano, S. O.; Intini, F. P.; Natile, G.; Marzilli, L. G. J. Am. Chem. Soc. 1997, 119, 8570-8571.

(20) Ano, S. O.; Intini, F. P.; Natile, G.; Marzilli, L. G. Inorg. Chem. 1999, 38, 2989-2999.

(21) Marzilli, L. G.; Intini, F. P.; Kiser, D.; Wong, H. C.; Ano, S. O.; Marzilli, P. A.; Natile, G. Inorg. Chem. 1998, 37, 6898-6905.

(22) Xu, Y.; Natile, G.; Intini, F. P.; Marzilli, L. G. J. Am. Chem. Soc. 1990, 112, 8177-8179.

(23) Andrepont, C.; Marzilli, P. A.; Marzilii, L. G. Inorg. Chem. 2012, 51, 11961-11970.

(24) Benedetti, M.; Tamasi, G.; Cini, R.; Marzilli, L. G.; Natile, G. Chem.-Eur. J. 2007, 13, 3131-3142.

(25) Carlone, M.; Marzilli, L. G.; Natile, G. Eur. J. Inorg. Chem. 2005, 1264-1273.

(26) Maheshwari, V.; Marzilli, P. A.; Marzilli, L. G. Inorg. Chem. 2008, 47, 9303-9313.

(27) Maheshwari, V.; Marzilli, P. A.; Marzilli, L. G. Inorg. Chem. 2011, 50, 6626-6636.

(28) Saad, J. A.; Scarcia, T.; Shinozuka, K.; Natile, G.; Marzilli, L. G. Inorg. Chem. 2002, 41, 546-557.

(29) Hambley, T. W. J. Chem. Soc., Dalton Trans. 2001, 2711-2718.

(30) Orbell, J. D.; Taylor, M. R.; Birch, S. L.; Lawton, S. E.; Vilkins, L. M.; Keefe, L. J. Inorg. Chim. Acta 1988, 152, 125-134.

(31) Benedetti, M.; Malina, J.; Kasparkova, J.; Brabec, V.; Natile, G. Environ. Health Perspect. 2002, 110, 779-782.

(32) Hirano, T.; Inagaki, K.; Fukai, T.; Alink, M.; Nakahara, H.; Kidani, Y. Chem. Pharm. Bull. 1990, 38, 2850-2852.

(33) Wang, D.; Zhu, G.; Huang, X.; Lippard, S. J. Proc. Natl. Acad. Sci. U.S.A. 2010, 107, 9584-9589.

(34) Johnstone, T. C.; Wilson, J. J.; Lippard, S. J. Inorg. Chem. 2013, 52, 12234-12249.

(35) Park, G. Y.; Wilson, J. J.; Song, Y.; Lippard, S. J. Proc. Natl. Acad. Sci. U.S.A. 2012, 109, 11987-11992.

(36) Zhu, G.; Myint, M.; Ang, W. H.; Song, L.; Lippard, S. J. Cancer Res. 2012, 72, 790-800.

(37) Carlone, M.; Marzilli, L. G.; Natile, G. Inorg. Chem. 2004, 43, 584-592.

(38) Price, J. H.; Williamson, A. N.; Schramm, R. F.; Wayland, B. B. Inorg. Chem. 1972, 11, 1280-1284.

(39) Nagao, H.; Komeda, N.; Mukaida, M.; Suzuki, M.; Tanaka, K. Inorg. Chem. 1996, 35, 6809-6815. 
(40) Gottleib, H. E.; Kotlyar, V.; Nudelman, A. J. Org. Chem. 1997, $62,7512-7515$.

(41) Sheldrick, G. M. Acta. Crystallogr., Sect. A: Found 2008, A64, $112-122$.

(42) Pitteri, B.; Annibale, G.; Marangoni, G.; Bertolasi, V.; Ferretti, V. Polyhedron 2002, 21, 2283-2291.

(43) Maheshwari, V.; Bhattacharyya, D.; Fronczek, F. R.; Marzilli, P. A.; Marzilli, L. G. Inorg. Chem. 2006, 45, 7182-7190.

(44) Pitteri, B.; Marangoni, G.; Cattalini, L.; Visentin, F.; Bertolasi, V.; Gilli, P. Polyhedron 2001, 20, 869-880.

(45) Britten, J. F.; Lock, C. J. L.; Pratt, W. M. C. Acta. Crystallogr., Sect. B: Struct. Crystallogr. Cryst. Chem. 1982, 38, 2148-2155.

(46) Ndinguri, M. W.; Fronczek, F. R.; Marzilli, P. A.; Crowe, W. E.; Hammer, R. P.; Marzilli, L. G. Inorg. Chim. Acta 2010, 363, 17961804.

(47) Lonnon, D. G.; Craig, D. C.; Colbran, S. B. Dalton Trans. 2006, 3785-3797.

(48) Sandlin, R. D.; Starling, M. P.; Williams, K. M. J. Inorg. Biochem. 2010, 104, 214-216.

(49) Carlone, M.; Fanizzi, F. P.; Intini, F. P.; Margiotta, N.; Marzilli, L. G.; Natile, G. Inorg. Chem. 2000, 39, 634-641.

(50) Christoforou, A. M.; Marzilli, P. A.; Marzilli, L. G. Inorg. Chem. 2006, 45, 6771-6781.

(51) Saad, J. S.; Scarcia, T.; Natile, G.; Marzilli, L. G. Inorg. Chem. 2002, 41, 4923-4935.

(52) Wong, H. C.; Intini, F. P.; Natile, G.; Marzilli, L. G. Inorg. Chem. 1999, 38, 1006-1014.

(53) Sullivan, S. T.; Ciccarese, A.; Fanizzi, F. P.; Marzilli, L. G. Inorg. Chem. 2001, 40, 455-462.

(54) Fanizzi, F. P.; Margiotta, N.; Lanfranchi, M.; Tiripicchio, A.; Pacchioni, G.; Natile, G. Eur. J. Inorg. Chem. 2004, 1705-1713. 